\title{
A survey of carbon monoxide and non-methane hydrocarbons in the Arctic Ocean during summer 2010
}

\author{
S. Tran ${ }^{1}$, B. Bonsang ${ }^{1}$, V. Gros ${ }^{1}$, I. Peeken ${ }^{2,3}$, R. Sarda-Esteve ${ }^{1}$, A. Bernhardt ${ }^{2}$, and S. Belviso ${ }^{1}$ \\ ${ }^{1}$ Laboratoire des Sciences du Climat et de l'Environnement, UMR8212, CEA/CNRS/UVSQ, CE Saclay, \\ Bat. 701 Orme des Merisiers, 91191, Gif-Sur-Yvette, France \\ ${ }^{2}$ Alfred Wegener Institute for Polar and Marine Research (AWI), Biological Oceanography, Am Handelshafen 12, \\ 27570, Bremerhaven, Germany \\ ${ }^{3}$ Center for Marine Environmental Sciences (MARUM), Leobener Strasse, 28359 Bremen, Germany \\ Correspondence to: B. Bonsang (bernard.bonsang@1sce.ipsl.fr)
}

Received: 5 March 2012 - Published in Biogeosciences Discuss.: 18 April 2012

Revised: 15 January 2013 - Accepted: 8 February 2013 - Published: 20 March 2013

\begin{abstract}
During the ARK XXV $1+2$ expedition in the Arctic Ocean carried out in June-July 2010 aboard the $\mathrm{R} / \mathrm{V}$ Polarstern, we measured carbon monoxide (CO), nonmethane hydrocarbons (NMHC) and phytoplankton pigments at the sea surface and down to a depth of $100 \mathrm{~m}$. The $\mathrm{CO}$ and NMHC sea-surface concentrations were highly variable; $\mathrm{CO}$, propene and isoprene levels ranged from 0.6 to $17.5 \mathrm{nmol} \mathrm{L}^{-1}, 1$ to $322 \mathrm{pmol} \mathrm{L}^{-1}$ and 1 to $541 \mathrm{pmol} \mathrm{L}^{-1}$, respectively. The $\mathrm{CO}$ and alkene concentrations as well as their sea-air fluxes were enhanced in polar waters off of Greenland, which were more stratified because of ice melting and richer in chromophoric dissolved organic matter (CDOM) than typical North Atlantic waters. The spatial distribution of the surface concentrations of $\mathrm{CO}$ was consistent with our current understanding of CO-induced UV photoproduction in the sea. The vertical distributions of the $\mathrm{CO}$ and alkenes were comparable and followed the trend of light penetration, with the concentrations displaying a relatively regular exponential decrease down to non-measurable values below $50 \mathrm{~m}$. However, no diurnal variations of $\mathrm{CO}$ or alkene concentrations were observed in the stratified and irradiated surface layers. On several occasions, we observed the existence of subsurface CO maxima at the level of the deep chlorophyll maximum. This finding suggests the existence of a nonphotochemical CO production pathway, most likely of phytoplanktonic origin. The corresponding production rates normalized to the chlorophyll content were in the range of those estimated from laboratory experiments. In general, the vertical distributions of isoprene followed that of the phytoplankton biomass. These data support the existence of a dominant
\end{abstract}

photochemical source of $\mathrm{CO}$ and light alkenes enhanced in polar waters of the Arctic Ocean, with a minor contribution of a biological source of $\mathrm{CO}$. The biological source of isoprene is observed in the different water masses but significantly increases in the warmer Atlantic waters.

\section{Introduction}

Carbon monoxide (CO) and non-methane hydrocarbons (NMHC) are ubiquitous in the remote marine troposphere and play a key role in determining the oxidizing capacity of Earth's atmosphere (Thompson, 1992; Prather et al., 2001). These compounds are major consumers of $\mathrm{OH}$ radicals and are strongly involved in lowering levels of this dominant atmospheric oxidant in the remote marine atmosphere. The lifetime of tropospheric CO is approximately 2 months (Crutzen, 1994; Prather, 1996), while the NMHC lifetimes range from a few hours up to several days (Logan et al., 1981; Atkinson, 1990). Isoprene has long been recognized as the dominant NMHC produced (Rasmussen and Went, 1965; Zimmerman et al., 1988). While terrestrial vegetation is the main source of isoprene, it has been shown that productive oceanic areas can emit isoprene at rates that can potentially influence the budget of reactive trace gases and oxidants in the remote atmosphere (Bonsang et al., 1992; Broadgate et al., 1997; Ayers et al., 1997; Lewis et al., 1999, 2001; Carslaw et al., 1999; Liakakou et al., 2007). In addition to its photochemical role, isoprene is also a precursor of secondary organic aerosols over continental areas (Claeys et al., 2004; 
Kanakidou et al., 2005 and references therein; Kroll and Seinfeld, 2008) and, possibly to a lesser extent, over the oceans (Arnold et al., 2009; Gantt et al., 2010).

Surveys of CO (Swinnerton and Lamontagne, 1974; Conrad et al., 1982; Stubbins et al., 2006; Xie et al., 2009) and NMHC concentrations (Rudolph and Ehhalt, 1981; Bonsang et al., 1988, 1992; Milne et al., 1995) in the ocean and the remote marine atmosphere have shown that the surface ocean is generally a source of reactive $\mathrm{CO}$ and NMHC because of its supersaturation with respect to the atmosphere. Estimates of the global marine emissions of $\mathrm{CO}$ span a large range from 3 to $600 \mathrm{Tg} \mathrm{Cyr}^{-1}$ (Bates et al., 1995; Zuo and Jones, 1995; Rhee, 2000; Zafiriou et al., 2003). The results of more recent assessments are of few $\mathrm{TgC}_{\mathrm{yr}}{ }^{-1}$; Stubbins et al. (2006) provided rather low fluxes of $3.7 \pm 2.6 \mathrm{Tg} \mathrm{C} \mathrm{yr}^{-1}$. The global marine emissions of NMHC are estimated to range between 2 and $50 \mathrm{TgC}^{-1}$. These emissions were obtained from regional measurements extrapolated to the global scale (Bonsang et al., 1988; Guenther et al., 1995; PlassDülmer et al., 1995; Ratte et al., 1998). For example, the value of $2 \mathrm{Tg} \mathrm{C} \mathrm{yr}^{-1}$ provided by Plass-Dülmer et al. (1995) was based on measurements conducted only in oligotrophic waters. The marine source of isoprene is estimated to range

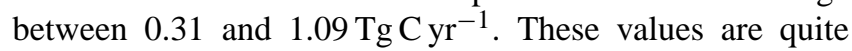
small compared to the estimated global emissions of isoprene of $\sim 400-750 \mathrm{Tg} \mathrm{C} \mathrm{yr}^{-1}$ (Guenther et al., 2006; Müller et al., 2008).

Marine $\mathrm{CO}$ and NMHC are hypothesized to be produced mainly photochemically from the interactions between UV-light and chromophoric dissolved organic matter (CDOM). Consequently, dissolved CO concentrations can display strong diurnal variations, with maxima in the early afternoon and minima at dawn (Swinnerton et al., 1970; Conrad et al., 1982; Jones, 1991; Bates et al., 1995; Zafiriou et al., 2008). The photochemical production of CO (Kettle, 2005; Zafiriou et al., 2008; Xie et al., 2009) is better understood than that of NMHC (Lee and Baker, 1992; Ratte et al., 1993, 1998; Riemer et al., 2000), and estimates of the global photoproduction of $\mathrm{CO}$ in sea water have been recently determined (Fichot and Miller, 2010). The production depends on the UV-absorption coefficient of CDOM in the water column and the CO quantum yield, which are both wavelength dependent and relatively well parameterized (Kettle, 2005; Xie et al., 2009; Fichot and Miller, 2010). Additional sources of $\mathrm{CO}$ have been recently reported: dark production (Zhang et al., 2008) and photoproduction on particles (Xie et al., 2009). Biological production of $\mathrm{CO}$ has also been recently observed in laboratory experiments, but the production pathways remain unclear (Gros et al., 2009). To date, there has been no evidence for the biological production of $\mathrm{CO}$ from field observations. Conversely, isoprene is known to be produced biologically (Bonsang et al., 1992, 2010; Shaw et al., 2003, 2010; Milne et al., 1995; Arnold et al., 2009), making it interesting to investigate the spatial and temporal variation of $\mathrm{CO}$ and isoprene concomitantly. The main sinks of oceanic $\mathrm{CO}$ are air-sea gas exchange and microbial oxidation (Zafiriou et al., 2003; Xie et al., 2005 and references therein; Zhang et al., 2008). For NMHC numerous studies have shown the existence of their utilization by microorganisms (Shennan, 2006; Brakstad and Bonaunet, 2006) as well as for low molecular weight hydrocarbons $\left(\mathrm{C}_{2}-\mathrm{C}_{6}\right)$ including isoprene (Alvarez et al., 2009; Palmer and Shaw, 2005) compared to heavier compounds such as petroleum hydrocarbons.

In polar regions, which are the most sensitive areas to the effects of global warming, only a few authors have reported oceanic CO and NMHC measurements (Linnenbom et al., 1973; Bates et al., 1995; Hudson and Ariya; 2007; Xie et al., 2009). The variability of seasonal ice cover, extremes of solar radiation and variable inputs of freshwater and terrestrial dissolved organic matter should impact photochemistry, airsea gas exchange and microbial processes (Frey and Smith, 2005; Retamal et al., 2007; Opsahl et al., 1999). It is expected that Arctic ice melting, leading to the reduction of ice thickness and ice coverage, would impact the depth of the mixed layer and of the euphotic zone, with a deeper penetration of light in the water column. This change should have major effects on plankton (Häder et al., 2007; Wängberg et al., 2008; Eilertsen and Holm-Hansen, 2000). In addition, due to the shrinking of sea ice, photochemical processes in the water and the air-sea exchange of gases will be enhanced. Moreover, the increases of sea surface temperature and dissolved organic matter inputs are expected to stimulate bacterial production (Xie et al., 2009).

Here, we report the results of the first study combining horizontal and vertical measurements of $\mathrm{CO}$, light NMHC, phytoplankton pigment concentrations, and a series of physical and chemical parameters to assess the production and removal pathways of CO and NMHC in North Atlantic and Arctic waters during the summer months.

\section{Study area}

Samples were collected during a seven-week-long cruise (ARK XXV1 + 2, 10 June-29 July 2010) on the R/V Polarstern from Bremerhaven, Germany, to Reykjavik, Iceland, through Longyearbyen (Greenland) and Svalbard (Fig. 1). This cruise covered a wide range of environments from populated/coastal areas (North Sea) to remote marine areas and from temperate areas to the high Arctic.

During this campaign, we carried out several transects, which will be presented here as four separate sections: two $\mathrm{N}-\mathrm{S}$ transects (section 1 from $58^{\circ} \mathrm{N}$ to $75^{\circ} \mathrm{N}$ and section 4 from $69^{\circ} \mathrm{N}$ to $78.5^{\circ} \mathrm{N}$ ) and two $\mathrm{E}-\mathrm{W}$ transects (section 2 at $75^{\circ} \mathrm{N}$ and section 3 at $78.5^{\circ} \mathrm{N}$ ). Special attention was paid to the long-term deep-sea observatory HAUSGARTEN in the eastern Fram Strait (section 3, magnified area in Fig. 1). The pack ice was met along the Greenland coast from 16 to 20 June and from 18 to 25 July. All of the date and time values are given in UTC. 


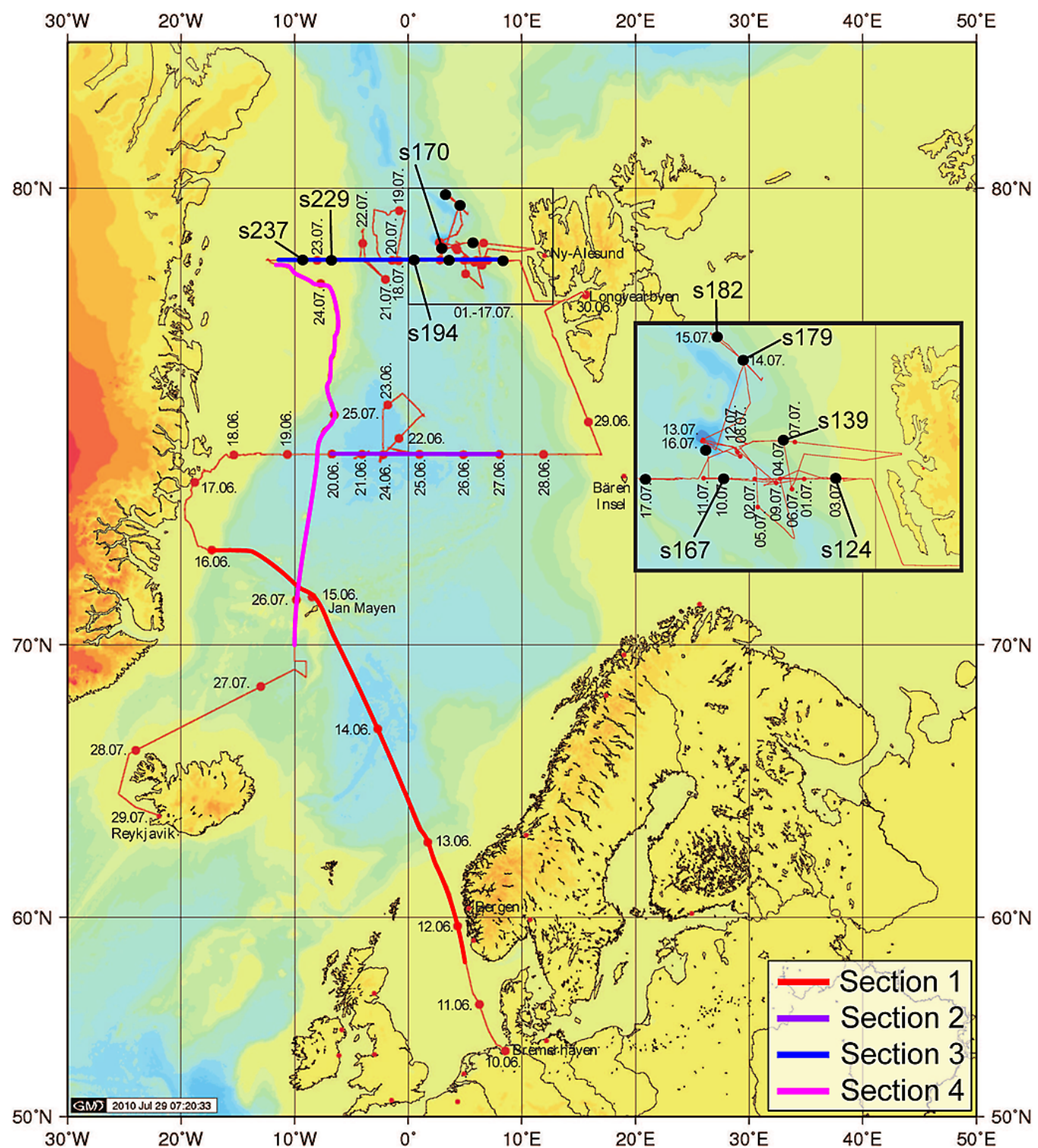

Fig. 1. Map of the cruise track of the R/V Polarstern ARK XXV $1+2$. The cruise began on 10 June 2010 in Bremerhaven, Germany, and ended on 29 July 2010 in Reykjavik, Iceland. The purple and yellow dots displayed in the magnified area show the position of stations of special interest.

Sea-surface measurements were performed using the ship's membrane pump. During the first part of the cruise (from 16 to 21 June 2010), the sea-surface sampling had to be interrupted to avoid damaging the membrane pump while crossing the thick pack ice. A total of 33 depth profiles were carried out, which were separated into two lots: 10 stations (section 2) and 23 stations (section 3). Only surface seawater measurements were carried out during section 1 and section 4.

The hydrology of the investigated area has been described by Rudels et al. (2004) and Blindheim and Rey (2004). The hydrology is particularly driven by two factors: seasonal changes in the water density in relation to the formation and melting of sea ice and the occurrence of precipitation that exceeds evaporation. These factors result in an outflow of low-density water through the upper layer and an inflow of high-density water through lower layers, with the establishment of a strong pycnocline in summer. The outflow is restricted to the western side of the basin, while the inflowing warm waters from the Atlantic Ocean spread through an intermediate layer. A full description of this complex hydrology can be found at http://www.incois.gov.in/Tutor/ regoc/pdffiles/colour/double/07P-Arctic-right.pdf. Using the method of Schlichtholz and Houssais (1999), different water masses were identified and classified (Table 1). The method described in their study was originally applied to Fram Strait 
Table 1. Classification of water masses (adapted from Schlichtholz and Houssais, 1999).

\begin{tabular}{lcc}
\hline Water mass & Temperature & Salinity \\
\hline Atlantic water with low salinity (AWs) & $\Theta>5^{\circ} \mathrm{C}$ & $S<34.4$ \\
Warm Atlantic water (WAW) & $\Theta>2{ }^{\circ} \mathrm{C}$ & $S>34.91$ \\
Fresh Atlantic water (FAW) & $\Theta>1{ }^{\circ} \mathrm{C}$ & $34.4<S<34.91$ \\
Polar water (PW) & $\Theta<0{ }^{\circ} \mathrm{C}$ & $S<34.7$ \\
& $\Theta>0{ }^{\circ} \mathrm{C}$ & $S<34.4$ \\
\hline
\end{tabular}

and water masses located between 77.15 and $81.15^{\circ} \mathrm{N}$. We have applied this method to our whole study area to sort our samples according to similar water characteristics. For sea surface temperature (SST) higher than $5^{\circ} \mathrm{C}$ and salinities lower than 34.4, a new class has been added (namely Atlantic water with low salinity due to freshwater inputs, AWs) to differentiate it from polar waters. This classification will facilitate the understanding of the influences of water masses on the distributions of gases.

\section{Experiments}

\subsection{Sample collection and storage}

Clean surface seawater was measured online. The water was pumped using a membrane pump from a $6 \mathrm{~m}$ depth inlet and transported through a Teflon pipe to the analytical laboratory. A $1 / 8^{\prime \prime}$ Teflon line was then used to connect the seawater inlet to the systems of gas extraction.

In addition, vertical profiles of dissolved $\mathrm{CO}$ and $\mathrm{NMHC}$ were performed at the different stations from the surface to a depth of $100 \mathrm{~m}$. Seawater samples were collected from standard $12 \mathrm{~L}$ Niskin bottles and then transferred to $1 \mathrm{~L} \mathrm{UV}$ protected glass bottles, which were overfilled before capping to eliminate headspace. The bottles were pre-rinsed with seawater prior to the sample collection. Six to ten depths were investigated according to the fluorescence profile provided by a "conductivity, temperature, depth" (CTD) sensor to obtain a better resolution at the depth of the chlorophyll $a$ maximum. During the first part of the cruise (sections 1 and 2), six samples were collected in duplicate. During the second part of the cruise (sections 3 and 4), the samples were not duplicated, and the vertical resolution was improved (i.e., 10 samples per vertical profile). The samples were not filtered, to avoid filtration artifacts and potential contamination. The surface water samples were analyzed immediately after collection, whereas the remaining samples were stored at $0{ }^{\circ} \mathrm{C}$ and analyzed subsequently within $10 \mathrm{~h}$.

Artifacts due to the sampling though the water pump and effects of the membrane were not particularly checked. However, surface or subsurface samples collected from the Niskin bottles during profiles studies and through the water pump during continuous surface measurements were compared. No significant difference was observed; this difference remained within the variability of $\mathrm{CO}$ and NMHC. Niskin bottles are known to be potentially a cause of erratic contamination (Xie et al., 2009). In this case we should have observed anomalous high concentrations particularly evident for depth samples representing 10 to $15 \%$ of our data of the profile stations.

A second possible cause of artifacts concerns the storage in glass bottles. To check for potential storage artifacts, we first conducted an experiment in which a series of 8 duplicated samples were successively analyzed for $\mathrm{CO}$ and NMHC within $7 \mathrm{~h}$. Samples were collected at station s68 $\left(75^{\circ} \mathrm{N}, 8.06^{\circ} \mathrm{W} ; 27\right.$ June, 10:30). The first flask was immediately analyzed after sampling, and the other flasks were stored at $0^{\circ} \mathrm{C}$ until further analysis. We observed that the $\mathrm{CO}$ concentrations, which were in the range of 0.1 to $0.8 \mathrm{nmol} \mathrm{L}^{-1}$, were significantly lower after several hours of storage. Because the flasks were perfectly sealed, gas exchange with the surrounding air was negligible; the CO loss followed roughly a first-order kinetics, which was on average equal to $(5.7 \pm 4.0) \times 10^{-6} \mathrm{~s}^{-1}$ or $0.5 \pm 0.3 \mathrm{~d}^{-1}$. In parallel, no significant change in the NMHC concentration was observed. A second set of experiments was conducted on ten duplicates of surface samples taken at station $s 75\left(75^{\circ} \mathrm{N}\right.$, $12.58 \mathrm{~W}$; 28 June, 16:30) with a CO initial concentration of $2.1 \mathrm{nmol} \mathrm{L}^{-1}$. We observed a more complicated pattern characterized by a relatively slow decrease during the first $4 \mathrm{~h}$ of $4.0 \times 10^{-6} \mathrm{~s}^{-1}\left(0.35 \mathrm{~d}^{-1}\right)$ followed by a rapid decrease of $2.0 \times 10^{-5} \mathrm{~s}^{-1}\left(1.7 \mathrm{~d}^{-1}\right)$ in the next $3 \mathrm{~h}$ of storage. These observations were in accordance with the hypothesis of a microbial consumption during the storage period, according to the range of kinetics observed by Xie et al. $(2005,2009)$ and Tolli and Taylor (2005).

Nevertheless, the CO levels were not corrected for losses during storage. Instead, we decided to maintain the following procedure: priority was always given to the analysis of the surface samples, which are enhanced in $\mathrm{CO}$, as will be shown later. Because the last samples analyzed were always the deepest ones, it is plausible that the steep vertical gradients observed between the surface and $100 \mathrm{~m}$ depth are in fact less steep than in reality due to some loss of $\mathrm{CO}$ in the deep samples. In contrast, no storage artifact was observed for NMHC, including isoprene.

\subsection{Analytical methods}

\subsubsection{Extraction of $\mathrm{CO}$ and NMHC}

The $\mathrm{CO}$ and the NMHC extraction from the seawater was performed using the same procedure: an automated gassegmented continuous-flow-equilibration method similar to that described by Xie et al. (2001). Two extraction cells were used and coupled to two different analyzers. Briefly, the extraction cell was a glass coil in which synthetic air and seawater were introduced continuously via a Teflon "tee" to form regularly spaced air-water segments. At the air-water interface, equilibration occurs by the diffusion of dissolved gases 
Table 2. Theoretical and experimental extraction yields for carbon monoxide and NMHC in our experimental conditions. Henry's law constants were taken from Sander (1999, available at http://www.ceset.unicamp.br/ mariaacm/ST405/Lei\%20de\%20Henry.pdf).

\begin{tabular}{lcccc}
\hline Compound & $\begin{array}{c}\text { Henry's law constant at } \\
25^{\circ} \mathrm{C} \mathrm{mol} \mathrm{L}^{-1} \mathrm{~atm}^{-1}\end{array}$ & $\begin{array}{c}\text { Theoretical extraction } \\
\text { yield }(\%)\end{array}$ & $\begin{array}{c}\text { Experimental } \\
\text { extraction yield }(\%)\end{array}$ & $\begin{array}{c}\text { Detection limit } \\
{[\mathrm{NMHC}]_{\text {min }}}\end{array}$ \\
\hline $\mathrm{CO}$ & $9.5 \times 10^{-4}$ & 97.7 & 56 & $0.08 \mathrm{nmol} \mathrm{L}^{-1}$ \\
\hline Ethene & $4.7 \times 10^{-3}$ & 90.0 & 90 & $0.93 \mathrm{pmol} \mathrm{L}^{-1}$ \\
Propene & $4.8 \times 10^{-3}$ & 89.6 & 88 & $0.61 \mathrm{pmol} \mathrm{L}^{-1}$ \\
1-butene & $4.7 \times 10^{-3}$ & 91.2 & 75 & $0.79 \mathrm{pmol} \mathrm{L}^{-1}$ \\
Isobutene & $4.7 \times 10^{-3}$ & 89.8 & 74 & $1.16 \mathrm{pmol} \mathrm{L}^{-1}$ \\
1-pentene & $2.5 \times 10^{-3}$ & 94.3 & 78 & $2.11 \mathrm{pmol} \mathrm{L}^{-1}$ \\
Isoprene & $1.3 \times 10^{-2}$ & 76.1 & 64 & $5.14 \mathrm{pmol} \mathrm{L}^{-1}$ \\
\hline Propane & $1.5 \times 10^{-3}$ & 95.6 & 95 & $1.47 \mathrm{pmol} \mathrm{L}^{-1}$ \\
$n$-butane & $1.2 \times 10^{-3}$ & 97.2 & 95 & $1.13 \mathrm{pmol} \mathrm{L}^{-1}$ \\
$n$-pentane & $8.0 \times 10^{-4}$ & 98.1 & 96 & $1.45 \mathrm{pmol} \mathrm{L}^{-1}$ \\
\hline
\end{tabular}

into the gas phase. Partially equilibrated gas was continuously flowing through a glass air-water separator and directed to the dedicated analyzer through a $1 / 8^{\prime \prime}$ stainless-steel line.

For the $\mathrm{CO}$ measurements, we used a $6.1 \mathrm{~m}$ long, $4 \mathrm{~mm}$ i.d. and $6 \mathrm{~mm}$ o.d. glass coil. The inlet water-sample flow rate $\left(f_{\mathrm{W}}\right)$ into the cell was regulated $\left(20 \mathrm{~mL} \mathrm{~min}^{-1}\right)$, and the flow rate of synthetic air $\left(f_{\mathrm{a}}\right)$ was $5 \mathrm{~mL} \mathrm{~min}^{-1}$. The ratio of $f_{\mathrm{a}} / f_{\mathrm{w}}$ was 0.25 , which was chosen to provide sensitivity and good extraction efficiency (Xie et al., 2001). The dimensions of the extraction cell were adapted to the NMHC measurements. Because the NMHC analyzer requires higher flow rates of air, we optimized the geometrical characteristics of the cell to obtain a larger exchange surface between the air-water segments. We used a $7.1 \mathrm{~m}$ long, $6 \mathrm{~mm}$ i.d. and $9 \mathrm{~mm}$ o.d. glass coil (custom-blown). The inlet water sample and gasextraction flow rates were both fixed at $20 \mathrm{~mL} \mathrm{~min}^{-1}$ for a $f_{\mathrm{a}} / f_{\mathrm{w}}$ ratio equal to 1 .

The water flow was regulated using a Gilson peristaltic pump (model Minipuls 3, Gilson Inc., Middleton, WI, USA) through $2.4 \mathrm{~mm}$ i.d. silicon tubes, and the synthetic air-flow rates were regulated using a mass-flow controller (model GFC17, 0-50 $\mathrm{mL} \mathrm{min}^{-1}$, Aalborg, Orangeburg, NY, USA). The flow rates, which were carefully determined in the laboratory, were regularly checked for stability aboard. The extraction yield (given in Table 2) was optimized in the laboratory using both seawater and fresh water (Milli-Q). The results showed no significant differences. The flow rates were optimized to provide the highest extraction efficiency (see Eq. A6 in Appendix A for NMHC). For CO, because the instrument flow rate should not exceed $5 \mathrm{~mL} \mathrm{~min}^{-1}$, the extraction efficiency was lower but was still in a reasonable range and very reproducible.

Table 2 shows the theoretical and experimental extraction efficiencies in the experimental conditions defined, i.e., an $f_{\mathrm{w}}$ of $20 \mathrm{~mL} \mathrm{~min}^{-1}$ and an $f_{\mathrm{g}}$ of 5 and $20 \mathrm{~mL} \mathrm{~min}^{-1}$ for $\mathrm{CO}$ and NMHC, respectively.

\subsubsection{Instruments for $\mathrm{CO}$ and NMHC analyses}

$\mathrm{CO}$ was measured using gas chromatography with a hot mercuric-oxide detector (RGD2, Trace Analytical, Menlo Park, CA, USA) directly coupled to the extraction cell. The system was composed of two 1-mL nominal volume stainless-steel injection loops (for samples and calibration, respectively). Prior to the field experiment, a series of tests was done in the laboratory in order to calibrate the sample loop with respect to standard loop: it consisted in measuring the standard alternatively in each loop. The difference observed was lower than $1 \%$, i.e., of the order of the precision of the measurements. The pre-column $(0.77 \mathrm{~m}$ length, $0.32 \mathrm{~cm}$ o.d., containing Unibeads $1 \mathrm{~S} 60 / 80 \mathrm{mesh})$ and the column $(0.77 \mathrm{~m}$ length, $0.32 \mathrm{~cm}$ o.d., containing molecular Sieve $13 \mathrm{X} 60 / 80 \mathrm{mesh})$ were heated at $95^{\circ} \mathrm{C}$, and the mercuric-oxide detector was operated at $265^{\circ} \mathrm{C}$. The $\mathrm{CO}$ retention time was $1.5 \mathrm{~min}$, and a complete chromatogram lasted for $2.5 \mathrm{~min}$.

NMHC measurements were performed using gas chromatography with a photoionization detector (GC-PID, Interscience, Global Analyser Solutions, Breda, NL). To remove water vapor, a Nafion dryer system (Perma Pure LLC, Toms River, NJ, USA) and a trap filled with magnesium perchlorate were placed upstream of the gas inlet. The air sample was pumped at $20 \mathrm{~mL} \mathrm{~min}^{-1}$ for $20 \mathrm{~min}$. The gas inlet was driven by two membrane valves that control the load and the injection into the trap. NMHC were trapped using three adsorbents (Carbosieve SIII, Carbopack B and Carbopack X) packed in one trap. Our original plans were to use the Peltier system to cool the trap at $-8^{\circ} \mathrm{C}$, but the system rapidly became inoperative. Therefore, we worked at ambient temperature, and consequently ethene was not properly quantified using our instrument. The trap was purged with nitrogen. A 
DB1 pre-column ( $8 \mathrm{~m}$ length, $0.32 \mathrm{~mm}$ i.d. $\times 1 \mu \mathrm{m}$ ) was used. This column is a nonpolar column that retains the heaviest NMHC ( $>\mathrm{C}_{6}$ ) prior to backflushing. The second column is an $\mathrm{Al}_{2} \mathrm{O}_{3}-\mathrm{Na}_{2} \mathrm{SO}_{4}$ capillary column for $\mathrm{C}_{2}-\mathrm{C}_{5}(30 \mathrm{~m}$ length, $0.32 \mathrm{~mm}$ i.d. $\times 5 \mu \mathrm{m}$ ). The flow rate of carrier gas (helium) was $3 \mathrm{~mL} \mathrm{~min}{ }^{-1}$. The gas chromatography oven was operated isothermally.

\subsubsection{Calibration of CO and NMHC and accuracy of the measurements}

The calibration of $\mathrm{CO}$ was performed automatically using a standard gas of CO in synthetic air $(187 \pm 20 \mathrm{ppbv}$ in a $40 \mathrm{~L}$ aluminum cylinder) provided and calibrated by the National Oceanic and Atmospheric Administration (NOAA, Boulder, CO, USA). Taking into account the experimental extraction efficiency for $\mathrm{CO}$, and the analytical conditions and parameters (respective volumes of the gas phase and water phase), $\sim 200 \mathrm{ppbv}$ of $\mathrm{CO}$ in the gas phase corresponds to an initial $\mathrm{CO}$ concentration in seawater of about $4 \mathrm{nmol} \mathrm{L}^{-1}$, which is in the range of the highest $\mathrm{CO}$ concentrations in the seawater generally observed at the surface. Due to the linearity of the detector, the calibration was extrapolated to lower and higher value. A sample and a standard were injected alternately, and each sample measurement was directly calibrated against the preceding standard. Humidity in the sample did not produce interferences in the calibration, but a regular shift of the $\mathrm{CO}$ retention time toward shorter values. The column was consequently periodically regenerated.

The NMHC measurements were calibrated twice a day using an NMHC standard provided by the National Physical Laboratory (NPL, Teddington, Middlesex, UK) containing 30 hydrocarbon species in nitrogen. The nominal concentrations of NMHC were in the range of 3.83 to $4.08 \mathrm{ppbv}$, and the precision was $0.08 \mathrm{ppbv}$ for each compound. The calibration gas was injected into the analyzer for $2 \mathrm{~min}$ at a flow rate of $30 \mathrm{~mL} \mathrm{~min}^{-1}$. The response of the detector was checked carefully for potential drifts. No significant drift was observed during the cruise. The absolute variability of the detector response was approximately $20 \%$ for propene (Fig. 2) and of the same order of magnitude for the other NMHC.

A blank measurement was performed systematically after the calibration to prevent from-memory effects. Blanks were also measured regularly by stopping the water flow in the extraction cell and allowing the air to circulate into the cell to the analyzer. The average value of all of the blanks was used to correct the $\mathrm{CO}$ and NMHC concentrations. The detection limit (DL) for $\mathrm{CO}$, considering the smallest peak area measurable, was $0.08 \mathrm{nmol} \mathrm{L}^{-1}$. For NMHC, the instrumental DL was relatively low, but the blanks displayed high levels and high variability (based on standard deviation of the blank, $\sigma_{\text {blank }}$ ), which exceeded the instrumental DL. The minimum detectable value $\left([\mathrm{NMHC}]_{\min }\right)$ reported in Table 2

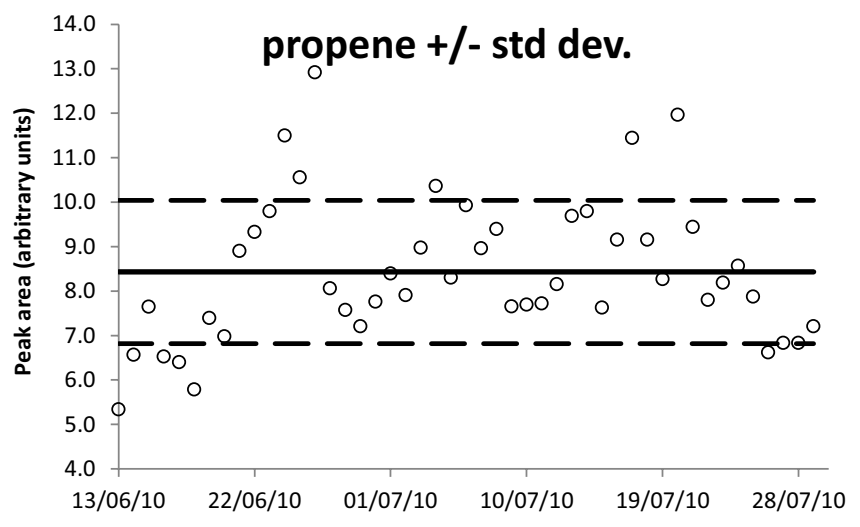

Fig. 2. Response of the detector to multiple injections of propene from the NPL calibration gas.

was therefore calculated as

$[\mathrm{NMHC}]_{\min }=[\mathrm{NMHC}]_{\text {measured }}-[\mathrm{NMHC}]_{\text {blank }} \geq \mathrm{DL}+\sigma_{\text {blank }}$.

On the whole, the precision of the $\mathrm{CO}$ and NMHC measurements was $2.5 \%$ and $10 \%$, respectively, and their accuracy was $12 \%$ and $20 \%$, respectively, including the reproducibility of the measurements, the blank and the standard variability.

Ethene was not considered, because it was not properly analyzed. Propene was the most abundant light alkene detected and quantified using our system. Propene accounted for $40 \%$ to $70 \%$ of the total alkenes, regardless of the total concentration of alkenes (Fig. 3). Hence, propene will be considered as representative of the whole family of light alkenes.

\subsubsection{Phytoplankton taxonomy assessed using marker pigments}

Biological samples were collected in the Greenland Sea and Fram Strait. Water sampling was conducted with Niskin bottles attached to a CTD (conductivity, temperature, depth) sensor (SBE 9 plus, Sea-Bird Electronics Inc, Washington D.C., USA) mounted on a stainless frame and, for the surface samples, with a membrane pump (6 $\mathrm{m}$ depth) from an overflow outlet of the gas-measurement line. In total, 650 samples were collected, with 122 surface samples and 528 samples from depth profiles in the upper $100 \mathrm{~m}$ of the water column. The depth resolution was between 6 to 10 samples per station.

For the determination of pigments, $1-3 \mathrm{~L}$ of seawater were filtered onto $25 \mathrm{~mm}$ Whatman $\mathrm{GF} / \mathrm{F}$ filters with a pressure of less than 120 mbar. After the filtration, the filters were folded, immediately frozen in liquid nitrogen and stored at $-80^{\circ} \mathrm{C}$. The collected samples were all analyzed in the laboratory within 8 months.

The samples were measured using a Waters HPLC system (Waters Corporation, Milford MA, USA) equipped with an autosampler (model 717 plus autosampler), an HPLC pump 


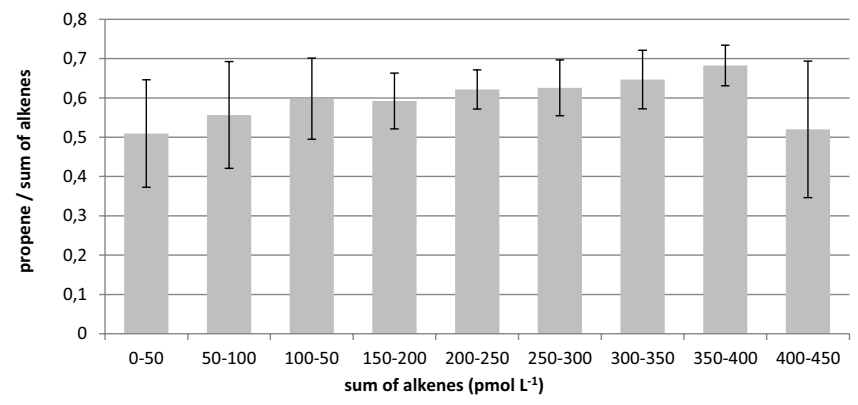

Fig. 3. Propene versus total light alkenes plotted against the total concentration of alkenes.

(model 600 HPLC LCD pump), a photodiode array detector (model PDA 2996), a fluorescence detector (model 2475 fluorescence detector) and the Empower software. For analytical preparation, $50 \mu \mathrm{L}$ of an internal standard (canthaxanthin) and $2 \mathrm{~mL}$ of acetone were added to each filter sample and homogenized for $20 \mathrm{~s}$. After centrifugation, the supernatant liquid was filtered through a $0.2 \mu \mathrm{m}$ filter and placed in Eppendorf cups from which aliquots $(100 \mu \mathrm{L})$ were transferred in the autosampler vials $\left(4^{\circ} \mathrm{C}\right)$. Just prior to analysis, the sample was premixed with a $1 \mathrm{M}$ ammonium acetate solution in a $1: 1(v / v)$ ratio in the autosampler and injected onto the HPLC system. The pigments were analyzed using reverse-phase HPLC with a VARIAN MicrosorbMV3 C8 column $(4.6 \times 100 \mathrm{~mm})$ and HPLC-grade solvents (Merck KGaA, Darmstadt, Germany). Solvent A consisted of $70 \%$ methanol and $30 \% 1 \mathrm{M}$ ammonium acetate, and solvent B contained $100 \%$ methanol. The gradient was modified following Barlow et al. (1997). The eluting pigments were detected by absorbance $(440 \mathrm{~nm})$ and fluorescence (Ex: $410 \mathrm{~nm}, \mathrm{Em}$ : > $600 \mathrm{~nm}$ ).

The pigments were identified by comparing their retention times with those of pure standards and algal extracts. Additional confirmation for each pigment was completed using on-line diode array absorbance spectra from 390-750 nm. The pigment concentrations were quantified based on the peak areas of external standards, which were spectrophotometrically calibrated using extinction coefficients published by Bidigare (1991) and Jeffrey and Vesk (1997). For correction of experimental losses and volume changes, the concentrations of the pigments were normalized to the internal standard canthaxanthin.

The taxonomic structure of the phytoplankton communities was derived from photosynthetic pigment ratios using the CHEMTAX $^{\circledR}$ program (Mackey et al., 1996), and the phytoplankton group composition is expressed in chlorophyll $a$ concentrations.

\subsubsection{Environmental data and ancillary measurements}

Standard meteorological information (wind speed and global radiation) was obtained from the ship's weather station (http://www.awi.de/de/infrastruktur/schiffe/ polarstern/bordwetterwarte/continuous_measurements/ sensor_information/).

Seawater characteristics (water temperature and salinity) were obtained from the Data Acquisition and Management System for Marine Research, which was updated continuously from on-board facilities (http://www.pangaea. de/PHP/CruiseReports.php?b=Polarstern). CDOM measurements were conducted with the FerryBox system of the Helmholtz-Zentrum Geesthacht (HZG). The sensor was a Cyclops-7 CDOM submersible fluorometer (Turner Designs Inc. Sunnyvale, CA, USA) with excitation/emission wavelength of respectively $325 \mathrm{~nm}$ and $425 \mathrm{~nm}$. This instrument was integrated in a FerryBox system, continuously monitoring data from the surface water $(6 \mathrm{~m})$. The entire instrument provides a self-cleaning every day, and no drift is usually observed. The values presented here were not calibrated and will be reported in arbitrary units to display their evolution along the cruise. The density was estimated from vertical CTD profiles (courtesy Gereon Budeus).

Optical in-water profiles were measured using two types of RAMSES hyperspectral radiometers (TriOS GmbH, Germany), which measured the radiance and irradiance in a wavelength range from $350 \mathrm{~nm}$ to $950 \mathrm{~nm}$ and with a spectral resolution of approximately $3.3 \mathrm{~nm}$ and a spectral accuracy of $0.3 \mathrm{~nm}$. The radiance sensor had a field of view of $7^{\circ}$, while the irradiance sensor had a cosine collector fixed in front of the instrument. All of the measurements were obtained with an automated integration time of the respective sensor between $4 \mathrm{~ms}$ and $8 \mathrm{~s}$. A reference irradiance device was placed above the water surface to monitor the downwelling incident sunlight and allow the normalization of the in-water measurements according to Stramski et al. (2008).

The profile data were averaged in discrete intervals of $2 \mathrm{~m}$ down to a depth of $48 \mathrm{~m}$, of $4 \mathrm{~m}$ down to a depth of $80 \mathrm{~m}$ and of $10 \mathrm{~m}$ for the measurements below $80 \mathrm{~m}$. Because surface waves strongly affected the measurements in the upper few meters, the upwelling irradiance and radiance at the surface were determined from deeper measurements that were extrapolated to the sea surface (Stramski et al., 2008; Ocean Optics Protocols For Satellite Ocean Color Sensor Validation, Revision 4, Volume III, and http://www.archive.org/details/nasa_techdoc_20030063139). PAR irradiance profiles were calculated as the integral of irradiances for wavelengths from $400 \mathrm{~nm}$ to $700 \mathrm{~nm}$ for each depth interval, and the UVA irradiance profiles were calculated as the integral for wavelengths from $350 \mathrm{~nm}$ to $400 \mathrm{~nm}$ (unfortunately, the sensor was not optimal and the measurements from $350 \mathrm{~nm}$ to $320 \mathrm{~nm}$ were questionable). A total of 22 radiometric profiles were collected from the CTD stations at noon down to a maximum depth of $190 \mathrm{~m}$. 


\section{Results}

\subsection{Variability of the surface $\mathrm{CO}$ and NMHC concentrations}

Throughout the cruise, the surface-seawater CO concentrations showed a high degree of variability. The values ranged from 0.6 to $17.5 \mathrm{nmol} \mathrm{L}^{-1}$, with a mean value of $4.2 \pm 3.0 \mathrm{nmol} \mathrm{L}^{-1}$. The mean background value was calculated during the period from 25 July at 18:00 UTC to 26 July at 12:20 UTC, during which a very low variability of CO concentration over at least $12 \mathrm{~h}$ occurred, and it was estimated at $1.6 \pm 0.9 \mathrm{nmol} \mathrm{L}^{-1}$. A few measurements of atmospheric $\mathrm{CO}$ were performed during our campaign and showed a quasiconstant level of approximately $93 \pm 9$ ppbv. Considering the Henry's law constant of $\mathrm{CO}\left(8.7 \times 10^{-4} \mathrm{~mol} \mathrm{~L}^{-1} \mathrm{~atm}^{-1}\right)$ (Yaws and Yang, 1992), the equilibrium between the air and sea surface would lead to a seawater concentration of $0.08 \mathrm{nmol} \mathrm{L}^{-1}$. Consequently, the seawater was always supersaturated, and the ocean served as a net source of $\mathrm{CO}$ to the atmosphere. Near shore waters and open ocean waters distinguished by bathymetry and salinity showed significant differences: the $\mathrm{CO}$ concentrations were higher in nearshore waters $\left(7.4 \pm 4.4 \mathrm{nmol} \mathrm{L}^{-1}\right)$ than in the open ocean $\left(4.0 \pm 2.5 \mathrm{nmol} \mathrm{L}^{-1}\right)$, most likely due to the input of additional CDOM from the rivers or meltwater (Cauwet and Sidorov, 1996; Wheeler et al., 1997; Gibson et al., 2001).

The NMHC and CO measurements were performed simultaneously. However, because an analysis of NMHC lasted for approximately $40 \mathrm{~min}$ in contrast to $5 \mathrm{~min}$ for $\mathrm{CO}$ analysis, there are fewer measurements of NMHC than of $\mathrm{CO}$ along the cruise track. Moreover, because daytime was usually dedicated to measurements at fixed stations, most of the surface NMHC measurements were performed at night.

Throughout the cruise, the isoprene concentrations varied widely, ranging from undetectable values (the detection limit was at $5 \mathrm{pmol} \mathrm{L}^{-1}$ ) to $541 \mathrm{pmol} \mathrm{L}^{-1}$, with an average of $26 \pm 31 \mathrm{pmol} \mathrm{L}^{-1}$. Mean and maximal values of $\mathrm{CO}$ and NMHC concentrations are presented in Table 3. The NMHC concentrations at the surface were in the range of a pmol L $\mathrm{L}^{-1}$ to several hundreds of $\mathrm{pmol} \mathrm{L}^{-1}$. The dominant class of light hydrocarbons was alkenes. The lowest levels of $\mathrm{CO}$ and propene were $0.6 \mathrm{nmol} \mathrm{L}^{-1}$ and $1 \mathrm{pmol} \mathrm{L}^{-1}$, respectively.

The wide range of variability in $\mathrm{CO}$ and propene concentrations is shown in the contour plots presented in Fig. 4, together with the distribution of CDOM. The CDOM levels were higher in the pack ice along the Greenland coast where $\mathrm{CO}$ and alkene levels were enhanced. In particular, hot spots of $\mathrm{CO}$ and propene concentrations occurred on the $\mathrm{N}-\mathrm{S}$ transect between 76 and $78^{\circ} \mathrm{N}$. Another hot spot of CO concentration occurred close to Jan Mayen Island, but unfortunately no alkene measurements were conducted in this region. Similarly, low concentrations of $\mathrm{CO}$ and propene were simultaneously observed when low concentrations of CDOM occurred.
Table 3. Mean and maximum concentrations of $\mathrm{CO}$ and NMHC recorded during the cruise.

\begin{tabular}{|c|c|c|c|}
\hline & $\left(\mathrm{nmol} \mathrm{L}^{-1}\right)$ & Mean $\pm 1 \mathrm{SD}$ & Maximal value \\
\hline & $\mathrm{CO}$ & $4.2 \pm 3$ & 17.5 \\
\hline & $\left(\operatorname{pmol} L^{-1}\right)$ & Mean \pm 1 SD & Maximal value \\
\hline \multirow{5}{*}{ 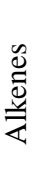 } & Propene & $80 \pm 58$ & 322 \\
\hline & 1-butene & $10 \pm 13$ & 101 \\
\hline & Isobutene & $24 \pm 20$ & 210 \\
\hline & 1-pentene & $8 \pm 12$ & 130 \\
\hline & Isoprene & $26 \pm 31$ & 541 \\
\hline \multirow{4}{*}{ 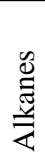 } & Propane & $11 \pm 32$ & 451 \\
\hline & Isobutane & $3 \pm 20$ & 320 \\
\hline & $n$-butane & $24 \pm 96$ & 1013 \\
\hline & $n$-pentane & $12 \pm 11$ & 64 \\
\hline
\end{tabular}

\subsection{Variations along the four sections}

Each of the following plots displays the surface concentrations of $\mathrm{CO}$, propene, sea-surface temperature, CDOM levels, global solar radiation, latitude, bathymetry and wind speed and chlorophyll $a$. Note that gaps in the records were due to several reasons, including the shift from surface sampling to vertical sampling, instrument calibration or instrument failure

Section one (Fig. 5) covered a large latitudinal range from the Norwegian coasts to Greenland and crossed the Norwegian Basin (cf. bathymetry Fig. 5d). The surface-seawater $\mathrm{CO}$ concentration ranged from 1.0 to $11.7 \mathrm{nmol} \mathrm{L}^{-1}$, with a mean value of $4.3 \pm 2.1 \mathrm{nmol} \mathrm{L}^{-1}$ (Fig. 5a). The average propene concentration was $89 \pm 58 \mathrm{pmol} \mathrm{L}^{-1}$. There was no clear correspondence between $\mathrm{CO}$ and propene. The seasurface temperature decreased towards the north from $11^{\circ} \mathrm{C}$ to $-0.6{ }^{\circ} \mathrm{C}$. There was a clear transition from Atlantic water (AW) masses to polar water (PW, Fig. 5b). A front was crossed while approaching Jan Mayen Island, characterized by a temperature drop of $3^{\circ} \mathrm{C}$ associated with a change of water masses from warm Atlantic water (WAW) to fresh Atlantic water (FAW). CDOM values were low all along this section (below 0.5 arbitrary units) but increased slightly on the Greenland shelf. The sunniest days were observed at the beginning of the transect (Fig. 5c), during which the total radiation reached $900 \mathrm{~W} \mathrm{~m}^{-2}$, while on the other days the maximum radiation was below $600 \mathrm{~W} \mathrm{~m}^{-2}$. There was a decreasing trend in wind speed (Fig. 5d) from $25 \mathrm{~m} \mathrm{~s}^{-1}$ at the beginning of the section to $3 \mathrm{~m} \mathrm{~s}^{-1}$ by the end. Surface chlorophyll $a$ measurements were performed (Fig. 5e), with values ranging from 1045 to $3102 \mathrm{ng} \mathrm{L}^{-1}$. Only two vertical profiles were recorded: one close to Jan Mayen Island and the second along the Greenland coast.

Section two (Fig. C1 shown in Appendix C) crossed the Greenland Basin roughly at $75^{\circ} \mathrm{N}$. The surface-seawater $\mathrm{CO}$ 
(a)

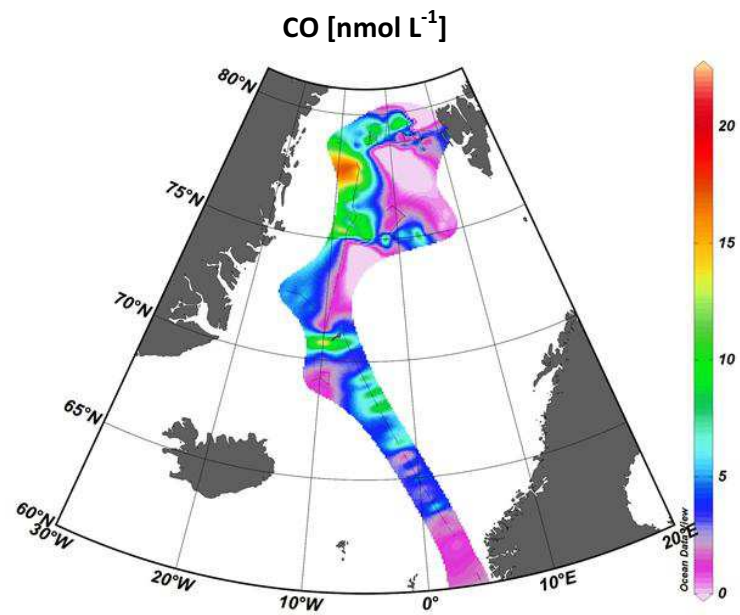

(b)

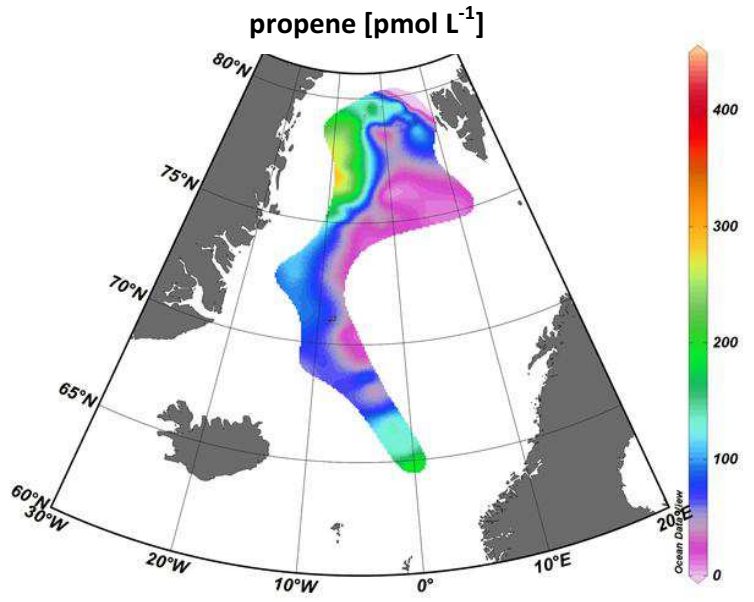

(c)

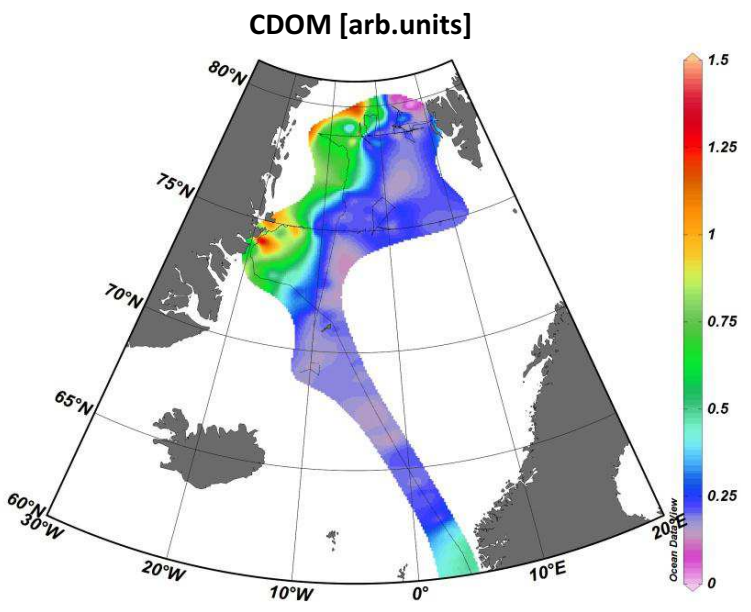

Fig. 4. Distributions of CO (a), propene (b) and CDOM (c) concentrations in surface waters (at a depth of $6 \mathrm{~m}$ ) throughout the study area.

concentration ranged from 0.5 to $10.5 \mathrm{nmol} \mathrm{L}^{-1}$, with a mean $\mathrm{CO}$ value of $4.3 \pm 2.6 \mathrm{nmol} \mathrm{L}^{-1}$. The propene concentrations were quite low (in the range of 1 to $72 \mathrm{pmol} \mathrm{L}^{-1}$ ) but showed the same pattern as CO. The average concentration

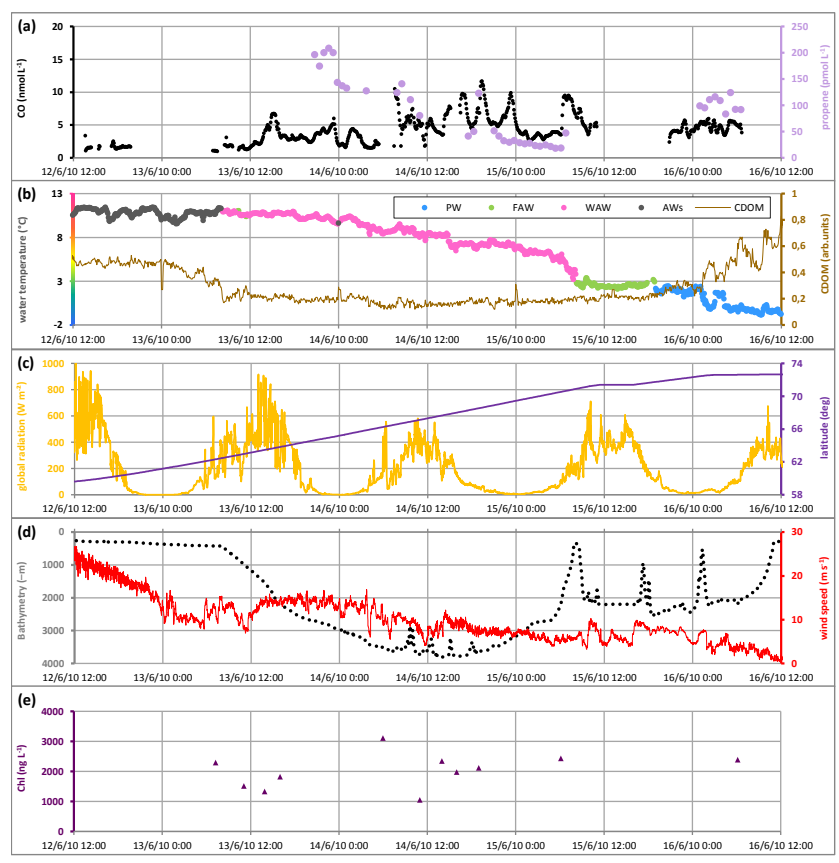

Fig. 5. Section 1. (a) Sea-surface $\mathrm{CO}\left(\mathrm{nmol} \mathrm{L}^{-1}\right)$ and propene (pmol L ${ }^{-1}$ ) concentrations; (b) sea-surface temperature $\left({ }^{\circ} \mathrm{C}\right)$, a classification of water masses $(\mathrm{PW}=$ polar water, $\mathrm{FAW}=$ fresh Atlantic water, WAW $=$ warm Atlantic water and AWs = Atlantic water with low salinity) and CDOM levels (in arbitrary units); (c) total radiation $\left(\mathrm{W} \mathrm{m}^{-2}\right)$ and latitude (deg); (d) bathymetry (m) and wind speed $\left(\mathrm{m} \mathrm{s}^{-1}\right)$; and (e) chlorophyll $a$ surface concentration $(\mu \mathrm{mol} \mathrm{L}-1)$.

of propene was $23 \pm 14 \mathrm{pmol} \mathrm{L}^{-1}$. The transect stations included FAW masses with an average SST of $2.8 \pm 0.4^{\circ} \mathrm{C}$ and constant low CDOM values. At the end of this transect and during a short route toward the north, WAW masses were encountered. Ten stations were sampled during the transect at $75^{\circ} \mathrm{N}$ while only three chlorophyll $a$ surface concentration measures were performed: on 21 June at 10:30 and 15:00, and on 22 June at 11:55, with chlorophyll $a$ values of respectively $1322 \mathrm{ng} \mathrm{L}^{-1}, 2582 \mathrm{ng} \mathrm{L}^{-1}$ and $4276 \mathrm{ng} \mathrm{L}^{-1}$.

Section 3 (Fig. C2 in Appendix C) covered the entire Fram Strait from east to west. The ship sometimes travelled north to reach the HAUSGARTEN area of investigation. The sampling from this section lasted 23 days. A total of 23 stations were investigated. The $\mathrm{CO}$ values ranged from 1.0 to $14.4 \mathrm{nmol} \mathrm{L}^{-1}$, with a mean surface $\mathrm{CO}$ concentration of $3.8 \pm 2.6 \mathrm{nmol} \mathrm{L}^{-1}$. The propene concentration ranged from 2 to $303 \mathrm{pmol} \mathrm{L}^{-1}$, with an average value of $87 \pm 44 \mathrm{pmol} \mathrm{L}^{-1}$. Chlorophyll $a$ surface concentrations were also documented and values ranged from 163 to $2606 \mathrm{ng} \mathrm{L}^{-1}$. During this section, the ship crossed four different water masses (PW, AWs, FAW and WAW), with sharp changes of the sea-surface temperature (up to $7^{\circ} \mathrm{C}$ ) while meeting PW. The CDOM values increased 5-fold at the end of this section. It appears that the $\mathrm{CO}$ concentrations were 

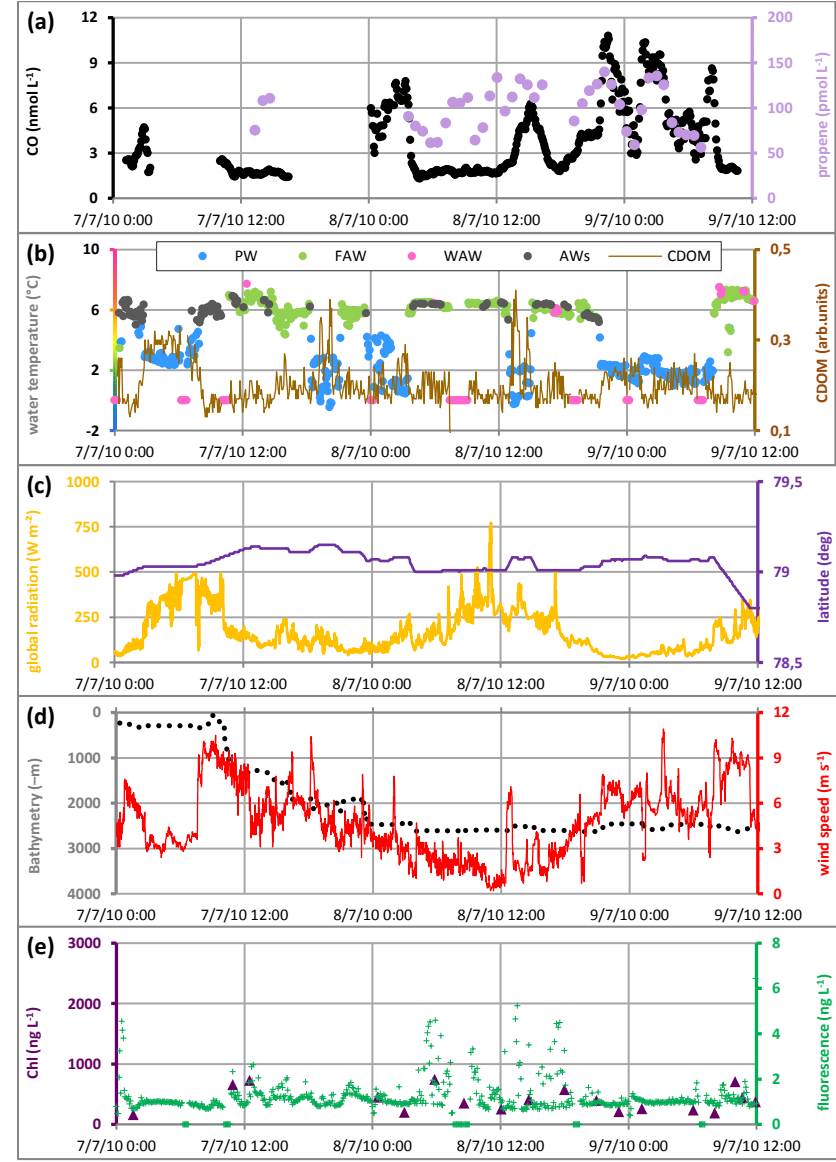

Fig. 6. Focus on section 3 from 7 to 9 July. (a) Seasurface $\mathrm{CO}(\mathrm{nmol} \mathrm{L}-1)$ and propene $\left(\mathrm{pmol} \mathrm{L}^{-1}\right)$ concentrations; (b) sea-surface temperature $\left({ }^{\circ} \mathrm{C}\right)$, a classification of water masses $(\mathrm{PW}=$ polar water, FAW $=$ fresh Atlantic water, WAW = warm Atlantic water and $\mathrm{AWs}=$ Atlantic water with low salinity) and CDOM levels (in arbitrary units); (c) total radiation $\left(\mathrm{W} \mathrm{m}^{-2}\right)$ and latitude (deg); (d) bathymetry (m) and wind speed $\left(\mathrm{m} \mathrm{s}^{-1}\right)$; and (e) chlorophyll $a$ surface concentration $(\mu \mathrm{mol} \mathrm{L}-1)$.

much more influenced by the presence of polar waters than by irradiance. For a better visibility, Figure 6 focuses on the period from 7 to 9 July.

The last section (Fig. 7) on the way back from the Greenland coast to Iceland lasted 3 days. Pack ice was present over the Greenland shelf. The polar waters were associated with the East Greenland Current and had high CDOM levels (Fig. 7b). The CO, propene and chlorophyll $a$ concentrations ranged from 1.1 to $17.5 \mathrm{nmol} \mathrm{L}^{-1}, 45$ to $322 \mathrm{pmol} \mathrm{L}^{-1}$ and 189 to $804 \mathrm{ng} \mathrm{L}^{-1}$ respectively. High CO concentrations (mean value of $5.9 \pm 4.9 \mathrm{nmol} \mathrm{L}^{-1}$ ) up to $17.5 \mathrm{nmol} \mathrm{L}^{-1}$ and high propene concentrations (average of $235 \pm 29 \mathrm{pmol} \mathrm{L}^{-1}$ ) were observed from 23 to 25 July (Fig. 7a). The CO concentrations seem to be influenced by the bathymetry and the occurrence of pack ice (Fig. 7d). The CO and propene concentrations showed the same trend except for the night of 25

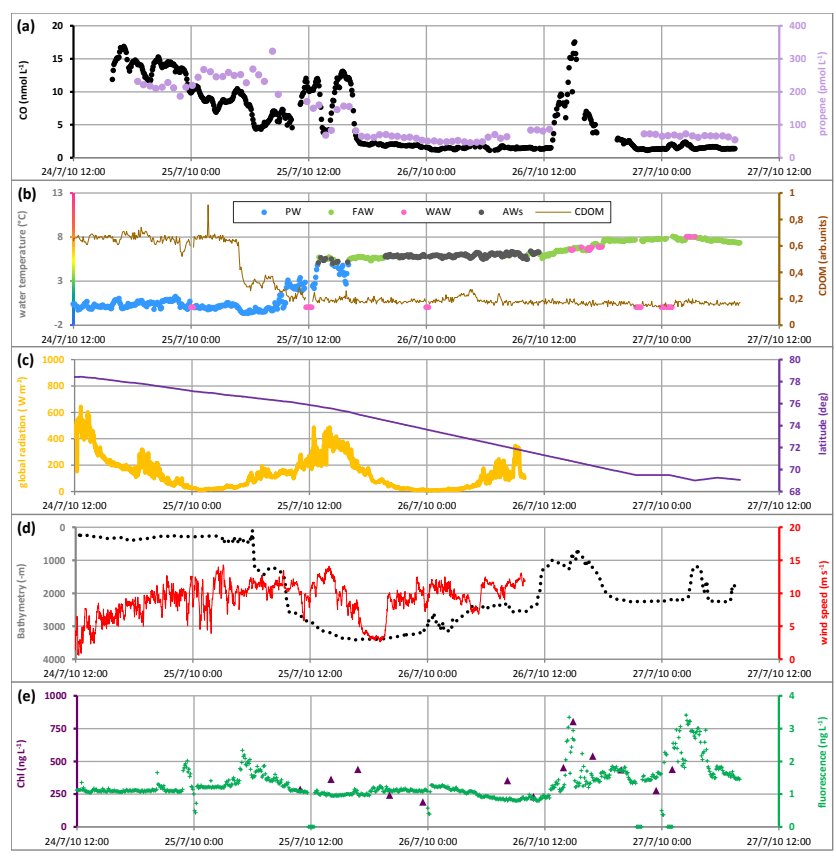

Fig. 7. Section 4. (a) Sea-surface $\mathrm{CO}\left(\mathrm{nmol} \mathrm{L}^{-1}\right)$ and propene (pmol L ${ }^{-1}$ ) concentrations; (b) sea-surface temperature $\left({ }^{\circ} \mathrm{C}\right.$ ), a classification of water masses $(\mathrm{PW}=$ polar water, FAW $=$ fresh Atlantic water, WAW $=$ warm Atlantic water and $\mathrm{AWs}=$ Atlantic water with low salinity) and CDOM levels (in arbitrary units); (c) total radiation $\left(\mathrm{W} \mathrm{m}^{-2}\right.$ ) and latitude (deg); (d) bathymetry $(\mathrm{m})$ and wind speed $\left(\mathrm{m} \mathrm{s}^{-1}\right)$; and (e) chlorophyll $a$ surface concentration $(\mu \mathrm{mol} \mathrm{L}-1)$.

July, when the $\mathrm{CO}$ concentration began to decrease, while the propene values remained high. Off of Jan Mayen Island (Fig. 7d), in FAW, a peak of CO concentration was measured $\left(17.5 \mathrm{nmol} \mathrm{L}^{-1}\right)$. Unfortunately, the propene concentrations were not measured, and the solar-radiation and windspeed sensors were switched off from 26 July in the morning (Fig. 7c, d).

In general, it appears that $\mathrm{CO}$ and NMHC concentrations appear to vary with surface-seawater temperature (Figs. 5 to 7). Specifically, between 7 to 9 July (Fig. 6) and from 24 to 25 July (Fig. 7), temperature drops of 5 to 7 degrees are associated with a simultaneous increase of $\mathrm{CO}$ and propene concentrations. On average, polar waters (PW), which are characterized by low temperature $\left(<5^{\circ} \mathrm{C}\right)$ and salinity $(<34.7)$, are enhanced in $\mathrm{CO}$ and propene (alkenes), with mean concentrations of $6.5 \mathrm{nmol} \mathrm{L}^{-1}$ and $125 \mathrm{pmol} \mathrm{L}^{-1}$, respectively (Table 4), whereas FAW or WAW contained 2 -fold lower concentrations. It is particularly interesting to note that isoprene displays an opposite trend, with concentrations significantly higher in WAW than in FAW and PW. 
Table 4. $\mathrm{CO}$ and NMHC mean concentrations ( \pm 1 standard deviation) sorted by water masses.

\begin{tabular}{|c|c|c|c|c|}
\hline & $\begin{array}{l}\text { Atlantic water, } \\
\text { low salinity }\end{array}$ & Polar water & $\begin{array}{r}\text { Fresh Atlantic } \\
\text { water }\end{array}$ & $\begin{array}{r}\text { Warm Atlantic } \\
\text { water }\end{array}$ \\
\hline $\mathrm{CO}\left(\mathrm{nmol} \mathrm{L}^{-1}\right)$ & $2.5 \pm 1.7$ & $6.5 \pm 3.2$ & $3.4 \pm 2.4$ & $3.3 \pm 2.2$ \\
\hline propene $\left(\mathrm{pmol} \mathrm{L}^{-1}\right)$ & $63.6 \pm 23.8$ & $124.8 \pm 60.6$ & $58.4 \pm 36.1$ & $51.2 \pm 49.8$ \\
\hline 1-butene $\left(\mathrm{pmol} \mathrm{L}^{-1}\right)$ & $5.8 \pm 3.2$ & $21.1 \pm 15.6$ & $4.8 \pm 6.4$ & $3.7 \pm 5.2$ \\
\hline isobutene $\left(\mathrm{pmol} \mathrm{L}^{-1}\right)$ & $12.8 \pm 9.8$ & $27.8 \pm 17.9$ & $20.4 \pm 12.5$ & $26.8 \pm 28.1$ \\
\hline 1-pentene $\left(\mathrm{pmol} \mathrm{L}^{-1}\right)$ & $3.3 \pm 2.6$ & $13.4 \pm 10.1$ & $6.4 \pm 15.0$ & $3.4 \pm 11.2$ \\
\hline isoprene $\left(\mathrm{pmol} \mathrm{L}{ }^{-1}\right)$ & $23.4 \pm 31.0$ & $14.5 \pm 11.5$ & $24.8 \pm 19.1$ & $42.5 \pm 49.6$ \\
\hline
\end{tabular}

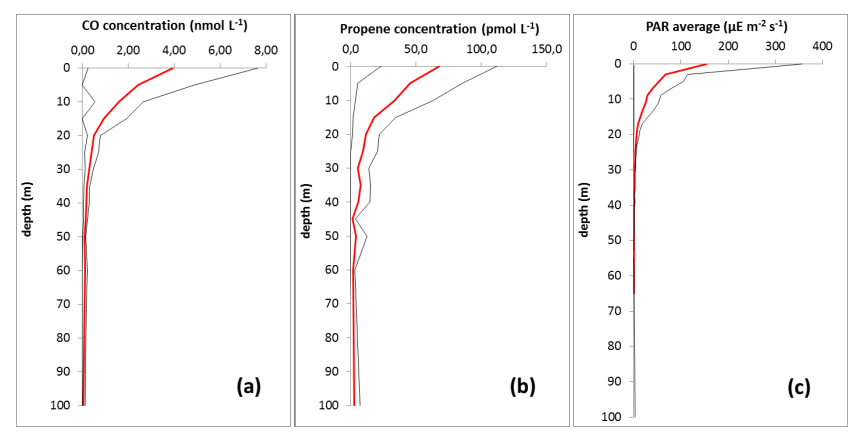

Fig. 8. Mean vertical profiles (in red) \pm standard deviation (in black) of $\mathrm{CO}$ (a) and propene (b) concentrations and the vertical distribution of PAR (c) for the whole cruise.

\subsection{Vertical distributions of $\mathrm{CO}$ and NMHC concentrations}

All of the vertical profiles were first plotted together and averaged, and the mean depth profiles of $\mathrm{CO}$ and light alkenes down to a depth of $100 \mathrm{~m}$ are displayed in Fig. 8. The concentrations show a regular decrease with depth comparable to that of light penetration (PAR, Fig. 8 and UVA, Fig. 10).

In the case of isoprene, its vertical distribution is more consistent with the chlorophyll $a$ distribution than with the profile of the light-penetration curve (Fig. 9) and is characterized by a systematic subsurface maximum between 10 and $30 \mathrm{~m}$ depth.

Table 5 summarizes, for the different stations identified by their water masses, the main characteristics of the $\mathrm{CO}$ and propene vertical distribution (propene being assumed to be representative of the alkenes): the concentration at $5 \mathrm{~m}$ depth (the most frequently subsurface depth collected from Niskin bottles), the e-fold value and the coefficient of determination for an exponential fitted profile.

PW stations (and particularly stations s224 and s237) with significant sea-ice coverage had the highest concentrations of $\mathrm{CO}$ (5.5 and $12.2 \mathrm{nmol} \mathrm{L}^{-1}$ respectively). For propene, PW stations s182, s224 and s237 present also high CO levels at the surface (146 to $149 \mathrm{pmol} \mathrm{L}^{-1}$ ). Besides this highest gas concentrations in a shallow mixed layer $(12 \mathrm{~m}, 14 \mathrm{~m}$ and $15 \mathrm{~m}$ respectively for stations s182, s224 and s237), we ob-
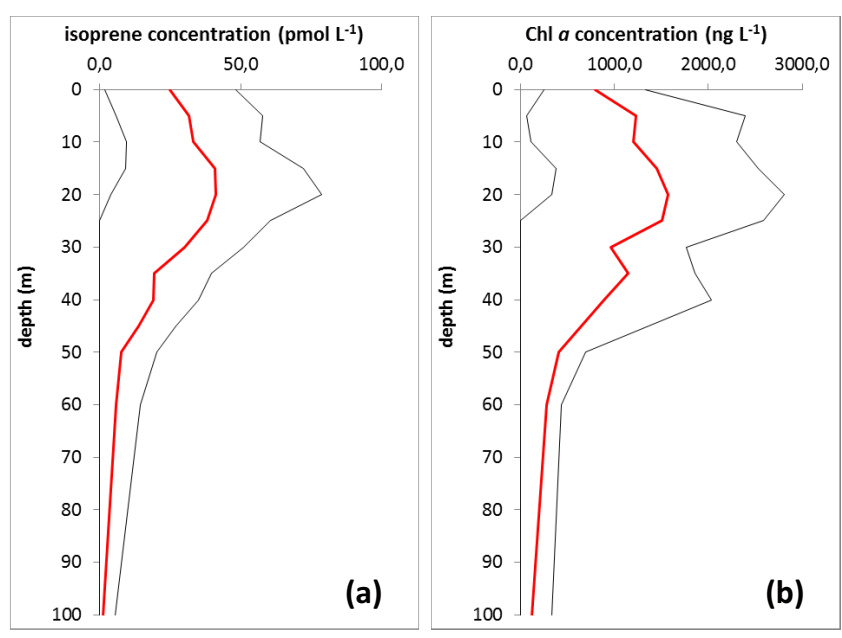

Fig. 9. Mean vertical profiles of isoprene (a) and chlorophyll $a$ (b) concentrations for the whole cruise. Red lines represent mean concentrations, and dark lines correspond to the standard deviation.

served a steep decrease of concentration with depth (e-fold for $\mathrm{CO}$ respectively of 6.3 to $8.4 \mathrm{~m}$ for $\mathrm{CO} ; 13.2$ to 15.4 for propene). In contrast, in open-water stations in AW or WAW (e.g., stations s64 to s170, and station s194), the concentrations at the surface are significantly lower and the e-fold significantly greater for $\mathrm{CO}$ and propene, as shown in Fig. 10, which compares to typical PW and AW stations. The vertical distributions of $\mathrm{CO}$ and propene are clearly influenced by the light profile, and generally the vertical gradients of $\mathrm{CO}$ and propene appear steeper in PW stations.

\subsection{Sea-air fluxes}

From the entire dataset we estimated the sea-air flux of the different gases. For this aim, sea-air fluxes were determined from the measurements taken at $6 \mathrm{~m}$ depth and the transfer velocity parameterizations available from Wanninkhof (1992) and Liss and Merlivat (1986). The Schmidt numbers (Appendix B) were described as a quartic function of the sea surface temperature. We made the distinction between the different water masses according to the classification in Table 1 . This statistical analysis was therefore based on a total 
Table 5. Locations of the station during the ARK XXV cruise.

\begin{tabular}{|c|c|c|c|c|c|c|c|c|c|c|c|c|c|}
\hline \multirow{2}{*}{$\begin{array}{l}\text { Station } \\
{ }^{\circ} \mathrm{N}\end{array}$} & \multirow{2}{*}{$\begin{array}{l}\text { Water } \\
\text { mass }\end{array}$} & \multirow[t]{2}{*}{ Date/Hour } & \multirow[t]{2}{*}{ Lat. } & \multirow[t]{2}{*}{ Long. ${ }^{\mathrm{a}}$} & \multirow{2}{*}{$\begin{array}{l}\text { Wind } \\
\text { speed } \\
\mathrm{m} \mathrm{s}^{-1}\end{array}$} & \multirow{2}{*}{$\begin{array}{l}\text { SST } \\
{ }^{\circ} \mathrm{C}\end{array}$} & \multirow{2}{*}{$\begin{array}{r}\text { ML } \\
\text { depth } \\
\mathrm{m}\end{array}$} & \multicolumn{3}{|c|}{$\mathrm{CO}$} & \multicolumn{3}{|c|}{ Propene } \\
\hline & & & & & & & & $\mathrm{nmol} \mathrm{L}^{-1 \mathrm{~b}}$ & e-fold $\mathrm{m}$ & $R^{2 \mathrm{c}}$ & $\mathrm{pmol}^{-1 b}$ & e-fold $\mathrm{m}$ & $R^{2 \mathrm{c}}$ \\
\hline S1 & AW & 15 Jun 13:25 & 71.40 & -8.45 & 6.7 & 1.47 & 27 & 3.95 & 20.5 & 0.927 & 26.75 & 51.2 & 0.908 \\
\hline S2 & PW & 17 Jun 17:25 & 74.64 & -17.99 & 4.4 & -1.32 & 28 & 1.90 & 9.5 & 0.947 & 62.24 & 48.5 & 0.934 \\
\hline S5 & PW & 18 Jun 03:50 & 74.91 & -16.45 & 6.1 & -1.60 & nd & 0.94 & 29.2 & 0.906 & & & \\
\hline S9 & PW & 18 Jun $15: 45$ & 75.00 & -14.45 & 3.0 & -1.44 & 20 & 1.77 & 16.9 & 0.830 & 70.77 & 34.1 & 0.862 \\
\hline S14 & PW & 19 Jun 00:35 & 75.00 & -12.54 & 4.1 & 1.86 & 20 & 0.51 & 23.6 & 0.896 & 16.96 & 49.3 & 0.724 \\
\hline S20 & FAW & 19 Jun 13:10 & 75.00 & -10.59 & 4.4 & 2.72 & 28 & 0.67 & 33.6 & 0.641 & 8.84 & ND & 0.017 \\
\hline S25 & FAW & 20 Jun 08:30 & 75.00 & -7.35 & 4.7 & 1.02 & 18 & 4.33 & 14.6 & 0.970 & 35.72 & 24.0 & 0.942 \\
\hline S41 & FAW & 23 Jun 05:35 & 76.21 & -1.15 & 8.5 & 2.26 & 45 & 1.25 & 22.5 & 0.963 & 13.51 & 42.2 & 0.988 \\
\hline S44 & FAW & 23 Jun 15:45 & 76.00 & -2.22 & 5.4 & 1.92 & 40 & 2.06 & 11.2 & 0.975 & 12.13 & 20.1 & 0.880 \\
\hline S64 & WAW & 26 Jun 14:50 & 75.00 & 5.49 & 6.4 & 4.98 & 32 & 0.96 & 28.3 & 0.789 & 10.38 & 11.3 & 0.960 \\
\hline S68 & WAW & 27 Jun 10:30 & 75.00 & 8.06 & 16.0 & 5.50 & 40 & 0.84 & 19.8 & 0.921 & 6.89 & 62.9 & 0.912 \\
\hline S102 & WAW & 2 Jul 13:30 & 78.83 & 4.99 & 2.6 & 5.78 & 25 & 4.29 & 15.3 & 0.930 & 61.67 & 10.6 & 0.947 \\
\hline S111 & AW & 3 Jul 09:00 & 78.83 & 8.67 & 3.2 & 5.77 & 10 & 1.97 & 16.2 & 0.761 & 31.87 & 10.5 & 0.849 \\
\hline S124 & AW & 3 Jul 21:55 & 78.9 & 6.77 & 3.6 & 6.08 & 30 & 2.18 & 25.0 & 0.840 & 19.68 & 7.7 & 0.885 \\
\hline S129 & AW & 5 Jul 16:05 & 78.92 & 4.99 & 2.8 & 5.41 & 18 & 2.58 & 18.1 & 0.959 & 36.74 & 6.1 & 0.943 \\
\hline S134 & AW & $6 \mathrm{Jul}$ 17:55 & 79.03 & 7.00 & 3.9 & 4.98 & 5 & 1.15 & 15.7 & 0.936 & 26.51 & 5.8 & 0.983 \\
\hline S136 & AW & 7 Jul 02:55 & 79.03 & 11.09 & 4.8 & 2.35 & 15 & 3.02 & 17.5 & 0.879 & 56.88 & 8.6 & 0.978 \\
\hline S139 & WAW & 7 Jul 17:10 & 79.11 & 4.61 & 4.8 & 4.82 & 45 & 0.87 & 19.2 & 0.838 & 21.06 & 21.0 & 0.583 \\
\hline S157 & WAW & 9 Jul 19:30 & 78.84 & 5.48 & 4.6 & 6.24 & nd & & & nd & 91.96 & 15.2 & 0.961 \\
\hline S167 & WAW & $10 \mathrm{Jul} 08: 10$ & 78.83 & 4.20 & 6.2 & 6.42 & 50 & 1.24 & 27.1 & 0.929 & 30.65 & 13.1 & 0.860 \\
\hline S170 & AW & $11 \mathrm{Jul} 23: 50$ & 79.15 & 2.75 & 2.7 & 3.94 & 40 & 2.21 & 18.7 & 0.893 & 60.94 & 11.2 & 0.921 \\
\hline S173 & PW & $12 \mathrm{Jul}$ 13:00 & 79.00 & 4.30 & 2.1 & 0.02 & 15 & & & nd & 40.56 & 16.2 & 0.796 \\
\hline S179 & AW & $14 \mathrm{Jul}$ 10:40 & 79.73 & 4.47 & 2.8 & 6.11 & 10 & 1.25 & 13.4 & 0.963 & 26.42 & 16.1 & 0.729 \\
\hline S182 & PW & $15 \mathrm{Jul} 08: 40$ & 79.93 & 3.09 & 8.8 & 0.75 & 12 & 2.07 & 10.0 & 0.972 & 146.05 & 7.1 & 0.931 \\
\hline S185 & PW & $16 \mathrm{Jul} 02: 45$ & 79.28 & 4.33 & 12.7 & 2.35 & 15 & 1.89 & 14.2 & 0.925 & 47.38 & 13.3 & 0.982 \\
\hline S194 & AW & 17 Jul 11:40 & 78.83 & 0.40 & 7.5 & 4.55 & 15 & 3.73 & 11.4 & 0.984 & 33.81 & 12.9 & 0.967 \\
\hline S200 & PW & $18 \mathrm{Jul}$ 01:35 & 78.83 & 1.90 & 2.9 & 6.02 & 40 & 1.13 & 18.9 & 0.897 & 14.73 & 15.5 & 0.872 \\
\hline S203 & AW & $18 \mathrm{Jul}$ 13:00 & 78.83 & -0.80 & 3.7 & 5.21 & 20 & & & nd & 36.33 & 14.0 & 0.890 \\
\hline S211 & PW & $20 \mathrm{Jul}$ 12:55 & 78.84 & -1.44 & 13.0 & 1.47 & 20 & & & nd & 29.10 & 7.2 & 0.895 \\
\hline S216 & PW & $21 \mathrm{Jul}$ 01:15 & 78.83 & -3.00 & 8.86 & 0.28 & 20 & 1.60 & 11.8 & 0.911 & 30.12 & 19.2 & 0.736 \\
\hline S224 & PW & $22 \mathrm{Jul}$ 23:25 & 78.83 & -4.93 & 7.37 & -1.26 & 14 & 5.52 & 8.4 & 0.818 & 145.64 & 13.2 & 0.686 \\
\hline S229 & PW & $23 \mathrm{Jul}$ 09:25 & 78.83 & -7.05 & 2.695 & -1.28 & 18 & 0.60 & 11.9 & 0.957 & 49.81 & 16.0 & 0.833 \\
\hline S237 & PW & 23 Jul 19:55 & 78.83 & -11.01 & 5.68 & 0.32 & 15 & 12.19 & 6.3 & 0.935 & 148.93 & 15.4 & 0.906 \\
\hline
\end{tabular}

a Longitude: - West +East,

$\mathrm{b}$ concentration of $\mathrm{CO}$ and propene measured at $5 \mathrm{~m}$ depth, and

c e-fold (m) and coefficient of determination $R^{2}$ for a fitted exponential decrease with depth.

of 3376 data points for $\mathrm{CO}$ fluxes, 327 for alkenes and 255 for isoprene. Owing to the rapid decrease of $\mathrm{CO}$ and alkenes with depth, a correction factor was applied to calculate the concentrations at the surface seawater. This correction factor was based on the e-fold value determined for the different water masses, considering in a first approach that the trace gases followed roughly an exponential decrease with depth described in Table 5 . The correction factor was respectively for of the order of $+31 \%$ to $+40 \%$ for $\mathrm{CO}$ (depending on the water masses) and $+23 \%$ to $+52 \%$ for alkenes. A correction factor was not applied for isoprene since the variability of the vertical distribution did not enable the derivation of a constant factor. However, on the basis of the average profile (Fig. 9) and the general increase of isoprene with depth in the upper layers, we can estimate that these fluxes are probably overestimated by $\sim 30 \%$.

Sea-air fluxes are presented for both parameterization (Table 6) for $\mathrm{CO}$ and for the major alkenes and isoprene. For $\mathrm{CO}$, sea-air fluxes increase from $6.1-14.1 \mu \mathrm{mol} \mathrm{m}^{-2} \mathrm{~d}^{-1}$ in At- lantic water with low salinity or warm Atlantic waters (AWs and WAW) to $11.0-23.6 \mu \mathrm{mol} \mathrm{m}^{-2} \mathrm{~d}^{-1}$ in cold waters (FAW and PW), i.e., roughly a factor 2 -fold. The same variability (2- or 3-fold increase) is observed for propene between Atlantic water and polar waters $\left(44-161 \mathrm{nmol} \mathrm{m}^{-2} \mathrm{~d}^{-1}\right.$ to 199-337 $\mathrm{nmol} \mathrm{m}^{-2} \mathrm{~d}^{-1}$ ); a difference of the same order of magnitude is also noted for 1-butene. Isoprene fluxes are very significant of the order of the propene or isobutene fluxes, but on the opposite they present their maximum in warm waters $\left(85-148 \mathrm{nmol} \mathrm{m}^{-2} \mathrm{~d}^{-1}\right)$ and their lowest values (4.6-8.8 $\mathrm{nmol} \mathrm{m}^{-2} \mathrm{~d}^{-1}$ ) in Atlantic waters (with low salinity). 
Table 6. Sea-air flux of CO and NMHC deduced from surface water measurements and piston velocities (averages, standard deviation). Fluxes are based on surface concentration estimated from the 6-m depth measurements and from the averaged e-fold values in the different water masses. The e-fold value measured for propene is used for all the alkenes. No correction is applied for isoprene, which must be considered as overestimated by about $30 \%$ on the basis of the averaged depth profile.

\begin{tabular}{llrr|rr|rr|r|r}
\hline & & \multicolumn{2}{c}{ Atlantic Water } & \multicolumn{2}{c}{ Polar Water } & Fresh Atlantic Water & \multicolumn{2}{c}{ Warm Atlantic Water } \\
& & L\&M & WAN & L\&M & WAN & L\&M & WAN & L\&M & WAN \\
\hline $\mathrm{CO}$ & $\mu \mathrm{mol} \mathrm{m}^{-2} \mathrm{~d}^{-1}$ & $6.15(7.5)$ & $14.1(19.1)$ & $13.6(10.6)$ & $23.6(18.6)$ & $11.0(10.8)$ & $20.5(8.7)$ & $8.4(6.5)$ & $13.8(10.4)$ \\
\hline Propene & $\mathrm{nmol} \mathrm{m}^{-2} \mathrm{~d}^{-1}$ & $53(31)$ & $93(42)$ & $199(148)$ & $337(252)$ & $44(66)$ & $90(122)$ & $98(155)$ & $161(249)$ \\
i-Butene & $\mathrm{nmol} \mathrm{m}^{-2} \mathrm{~d}^{-1}$ & $6.3(3.7)$ & $11(5.2)$ & $41(29)$ & $69(50)$ & $26(47)$ & $54(87)$ & $54(63)$ & $91(102)$ \\
1-Butene & $\mathrm{nmol} \mathrm{m}^{-2} \mathrm{~d}^{-1}$ & $3.9(2.2)$ & $6.8(3.1)$ & $33(31)$ & $56(52)$ & $1.3(2.4)$ & $3.0(4.6)$ & $4.9(15)$ & $8.7(28)$ \\
Isoprene & $\mathrm{nmol} \mathrm{m}^{-2} \mathrm{~d}^{-1}$ & $4.6(4.4)$ & $8.8(6.2)$ & $24(20)$ & $42(36)$ & $22(42)$ & $46(76)$ & $85(204)$ & $148(389)$ \\
\hline
\end{tabular}

L\&M: from the parametrization of Liss and Merlivat (1986)

WAN: from the parametrization of Wanninkhof (1992).

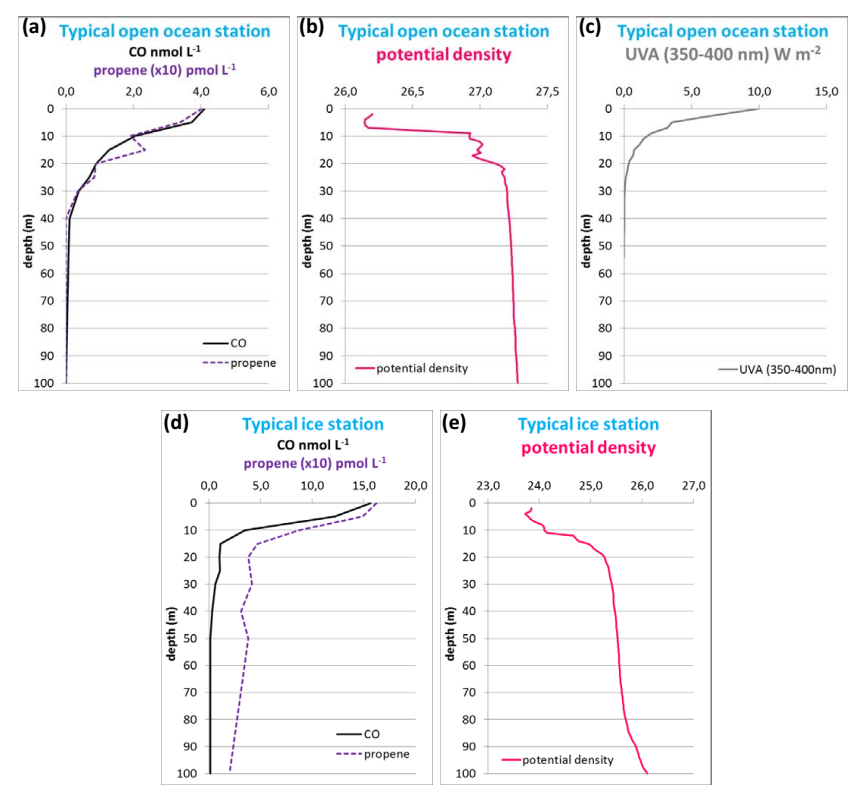

Fig. 10. $\mathrm{CO}\left(\mathrm{nmol} \mathrm{L}^{-1}\right)$ and propene $\left(\mathrm{pmol} \mathrm{L}^{-1}\right)(\mathbf{a}, \mathbf{d})$ concentrations and potential densities $(\mathbf{b}, \mathbf{e})$ of a typical open-ocean station (s194) and a typical ice station (s237). Vertical profile of UVA (from 350 to $400 \mathrm{~nm}$ ) penetration (c) measured at s194 in the open ocean.

\section{Discussion}

\subsection{Surface concentrations and sea-air fluxes}

For dissolved CO, our results are comparable to other measurements of surface water in the Arctic Ocean, particularly with the first measurements by Swinnerton and Lamontagne (1974), who report an average concentration of $2.5 \mathrm{nmol} \mathrm{L}^{-1}$. Recently, the CO concentration measured in the Beaufort Sea (during spring) ranged from 0.98 to $13 \mathrm{nmol} \mathrm{L}^{-1}$, with a mean value of $4.72 \pm 2.42 \mathrm{nmol} \mathrm{L}^{-1}$ (Xie et al., 2009). For other oceanic areas, the surface-seawater $\mathrm{CO}$ concentrations are in the range of 0.4 to $2.6 \mathrm{nmol} \mathrm{L}^{-1}$ over the Atlantic Ocean (Stubbins et al., 2006) and 0 to $5.8 \mathrm{nmol} \mathrm{L}^{-1}$ over the
Pacific Ocean (Bates et al., 1995). The values reported here were thus of the same order of magnitude. Nevertheless, the maximal values found in the Arctic Ocean were the highest among the previously reported $\mathrm{CO}$ measurements in the open ocean. For NMHC, our results are also in agreement with the previous data reported in the literature (Plass-Dülmer et al., 1995), but as no specific investigations of NMHC were performed in Arctic regions, a direct comparison with previous data cannot be made.

Concerning the sea-air fluxes of $\mathrm{CO}$, the values reported in the literature by various authors are in the range of 0.2 to $13 \mu \mathrm{mol} \mathrm{m}{ }^{-2} \mathrm{~d}^{-1}$ (Conrad et al., 1982; Bates et al., 1995) with averaged estimates from 1.9 to $2.7 \mu \mathrm{mol} \mathrm{m}^{-2} \mathrm{~d}^{-1}$ for the North or South Atlantic and Pacific Ocean (Bates et al., 1995; Stubbins et al., 2006). Higher values of the order of $20 \mu \mathrm{mol} \mathrm{m} \mathrm{m}^{-2} \mathrm{~d}^{-1}$ were however reported by Erikson (1989) and Gammon and Kelly (1990) in the same oceanic areas. Closer to our investigation area, sea-air fluxes in the Amundsen Gulf (Xie et al., 2009) span over a large range from 0.06 to $44 \mu \mathrm{mol} \mathrm{m}^{-2} \mathrm{~d}^{-1}$ with an average figure of $6.2 \mu \mathrm{mol} \mathrm{m}{ }^{-2} \mathrm{~d}^{-1}$ comparable to our lowest estimate in Atlantic waters. Clearly, sea-air fluxes of CO appeared significantly enhanced in polar or fresh Atlantic waters, and correspond to the highest range of values previously reported.

For alkenes, Plass-Dülmer et al. (1993) have estimated for the Atlantic Ocean $\left(8\right.$ to $\left.35^{\circ} \mathrm{N}\right)$ sea-air fluxes of propene of $100-300 \mathrm{nmol} \mathrm{m}^{-2} \mathrm{~d}^{-1}$ comparable to our estimate in WAW or PW, and for 1-butene an average of $157 \mathrm{nmol} \mathrm{m}^{-2} \mathrm{~d}^{-1}$, which is about 2 -fold greater than our observations but comparable to our estimate for the sum of butenes. As for $\mathrm{CO}$, sea-air fluxes of propene and of butenes in polar waters were significantly higher than in other water masses, and were in the range of the highest values previously reported. Isoprene emission rates in WAW are in the range of figures previously reported in the North Sea: 67.4 to $112 \mathrm{nmol} \mathrm{m}^{-2} \mathrm{~d}^{-1}$ (Broadgate et al., 1997; Palmer and Shaw, 2005). Our sea-air fluxes of isoprene in FAW and PW $\left(22-46 \mathrm{nmol} \mathrm{m}^{-2} \mathrm{~d}^{-1}\right)$ can be compared to the estimates of 
the same authors for high latitudes or subpolar areas, with a range of $31.6-51.6 \mathrm{nmol} \mathrm{m}^{-2} \mathrm{~d}^{-1}$ for the Bellingshausen Sea (Antarctica).

\subsection{Turnover of $\mathrm{CO}$, alkenes, and isoprene in the mixed layer and effect of temperature}

The mean vertical profiles of $\mathrm{CO}$ and selected NMHC concentrations measured in the upper $100 \mathrm{~m}$ of the ocean throughout the entire campaign showed that the concentrations of those compounds in the water column gradually decreased with depth (Fig. 8a and b), as reported in many other studies (Conrad et al., 1982; Johnson and Bates, 1996; Ohta, 1997; Kettle, 2005; Day and Faloona, 2009; Yang et al., 2011). This trend was characterized by a quasi-exponential decrease with a variable e-fold value of a few meters (for $\mathrm{PW}$ ) to $15-20 \mathrm{~m}$ (for AW), attributed to the rapid attenuation of the actinic flux available for CDOM photolysis. The highest $\mathrm{CO}$ concentration at each station was always observed at the sea surface and then decreased rapidly in the top $100 \mathrm{~m}$ layer. The variation patterns of $\mathrm{CO}$ concentration were comparable to those of photosynthetically active radiation (PAR) (Fig. 8c) and UVA penetration, indicating that the production at different depths was principally driven by the decrease of light intensity. In the absence of mixing, the $\mathrm{CO}$ profile would be expected to roughly coincide with that of UV penetration, according to other reports (Zafiriou, et al., 2003; Kettle, 2005; Xie et al., 2009).

Because the mean propene depth profile (Fig. 8b) and light $\mathrm{C}_{4}-\mathrm{C}_{5}$ alkenes presented the same pattern, a similar mechanism of production can be assumed, as already suggested by Ratte et al. (1998). Our results were thus in agreement with other studies and confirmed that $\mathrm{CO}$ and alkene concentrations have very similar production mechanisms in the euphotic zone, mainly driven by light (UV) penetration. The alkane concentrations seemed to be well mixed in the water column and did not show any significant variability (profiles not shown here). Ratte et al. (1998) investigated alkane measurements in seawater and described similar features. The authors concluded that alkane concentrations generally exhibited irregular fluctuations, and thus the factors determining alkane concentrations were different from those for propene and isoprene.

Many authors have already reported the existence of a deep-maximum pattern for isoprene concentration profiles (Bonsang et al., 1992; Milne et al., 1995), which was similar to that of phytoplankton productivity in terms of chlorophyll $a$ concentration.

Our results demonstrate the importance of the different variables that influence the temporal and spatial variability of $\mathrm{CO}$ or NMHC in the ocean. The surface variability of $\mathrm{CO}$ and NMHC and their vertical distributions in the euphotic zone depend on the combination of sources and sinks involving solar radiation, temperature, ventilation at the air-sea interface, CDOM content and phytoplankton biomass and dis- tributions. As a first approach, our results indicate that solar radiation drives the vertical distributions of $\mathrm{CO}$ and alkenes, whereas phytoplankton abundance is the dominant factor explaining the vertical structure of isoprene concentrations in the euphotic zone.

For all the measured species, one dominant sink effect in the mixed layer is the gas exchange at the seawater interface, usually described as wind-dependent piston velocity. Several parameterizations have been proposed; the most frequently used are the parameterizations of Liss and Merlivat (1986) based on tracer exchanges in wind tunnel and over lakes, or Wanninkhof (1992) for the open ocean. These parameterizations follow either a segmented linear dependence (Liss and Merlivat, 1986) or a polynomial dependence with the wind speed (Wanninkhof, 1992), and both are related by a power law dependence $(2 / 3$ or $1 / 2)$ of the Schmidt number $S c$ (or of diffusivity) for the exchanged species in seawater (Appendix B). Whereas the Liss and Merlivat parameterization seems more appropriate to describe gas exchanges over lakes, it is considered as a lower limit of the piston velocity. Moreover it was pointed out that the roles of breaking waves bubbles, and organic active material at the sea surface could introduce large uncertainties, which are difficult to estimate (Nightingale et al., 2000). Therefore, we will use both parameterizations, considering the Wanninkhof parameterization as an upper limit, and we used an average of these two approaches.

Microbial consumption is probably the most important term acting on the turnover of $\mathrm{CO}$ in surface seawater. The microbial consumption of $\mathrm{CO}$ has been intensively studied in various oceanic environments, and particularly in warm Atlantic and polar waters (Xie et al., 2005, 2009). According to these authors, microbial $\mathrm{CO}$ consumption follows a complex pattern from first-order kinetic at low substrate (CO) concentration (typically of the order of $2 \mathrm{nmol} \mathrm{L}^{-1}$ ) to zeroorder kinetics or even saturation at greater $\mathrm{CO}$ concentrations. This term seems to be strongly dependent on the water mass characteristics, and several parameterizations have been proposed, linearly depending on chlorophyll a, and following a linear or an exponential dependence on temperature (Xie et al., 2005). According to their proposed parameterization $\left(k_{\mathrm{CO}}\left(\right.\right.$ in $\left.\left.^{-1}\right)=0.053[\mathrm{chl} a]+0.0081\right)$ for a first-order consumption rate in the Beaufort Sea, which corresponds to water masses similar to the water masses that we have investigated, we tentatively derived a figure of a first-order consumption term (in $\mathrm{h}^{-1}$ ) of 0.0226 [chl $a$ ] -0.0038 (with a coefficient of determination $R^{2}$ of 0.82 ) based on our storage experiment at station $\mathrm{s} 68$ for a substrate concentration of $\mathrm{CO}$ lower than $2 \mathrm{nmol} \mathrm{L}^{-1}$, chlorophyll $a$ concentrations varying with depth from 0.3 to $1.2 \mu \mathrm{g} \mathrm{L}-1$, and a temperature of $5^{\circ} \mathrm{C}$. For higher $\mathrm{CO}$ concentrations ( 2 to $4 \mathrm{nmol} \mathrm{L}^{-1}$ typically), we used a saturation kinetic obtained by the same authors in open ocean waters of the Beaufort Sea of $0.06 \mathrm{nmol} \mathrm{L}^{-1} \mathrm{~h}^{-1}$. The temperature effect was not included in our parameterization, but it could have a significant effect, according to the 
linear dependence of $k_{\mathrm{CO}}$ pointed out by Xie et al. (2005). This effect can easily lead to a 2- or 3-fold uncertainty according to the range of temperature in the investigated water masses.

Whereas no significant effect of microbial consumption was observed for NMHC in our experiment on a time scale of $10 \mathrm{~h}$, this term is probably not negligible, because in the absence of a significant sink, alkenes should be transported by eddy diffusion downward below the mixed layer and the euphotic zone. Indeed, many studies have reported various mechanisms of hydrocarbon utilization by bacteria and microorganisms in sea water (Shennan, 2006; Brakstad and Bonaunet, 2006). For isoprene, a biological sink involving soil bacteria has been observed (Fall and Copley, 2000), but the degradation or oxidation by marine microorganisms is not clearly established (Shaw et al., 2003). However, an average value of $k_{\text {bio }}$ of $0.06 \mathrm{day}^{-1}$ has been tentatively used by Palmer and Shaw (2005) in global marine isoprene budgets. Considering the probable large variability of this sink with the temperature, we will however consider this effect as secondary importance in cold or polar waters. Other sinks, such as oxidation, similar to the reactions of alkenes and dienes with radical species correspond to very slow kinetics (Mill et al., 1978) and are most likely of minor importance (Riemer et al., 2000).

The vertical transport toward deeper layers will not be considered here as a first approximation, because the concentrations of the measured species fall to negligible values at the bottom of the euphotic zone, and consequently any advection or diffusion term should be close to zero.

From the characteristics of the different stations investigated, we derived therefore a rough estimation of the turnover of $\mathrm{CO}$ and isoprene in the mixed layer (Table 7) based on the best estimates of the microbial consumption term and the contribution of the sea-air exchange piston velocity $\left(K_{\mathrm{w}}\right)$ and the mixed layer depth $\left(Z_{\mathrm{ML}}\right)$ with a time constant given by

$k=\frac{K_{\mathrm{w}}}{Z_{\mathrm{ML}}}$.

On the whole, the $\mathrm{CO}$ turnover in the mixed layer varies between 0.1 and $1.7 \mathrm{~d}^{-1}$ with a mean value of $0.6 \pm 0.4 \mathrm{~d}^{-1}$. On the average, for $\mathrm{CO}$, the contribution to the global turnover in the mixed layer of the exchange with the atmosphere is of $\sim 24 \%$ for FAW or PW and $12 \%$ for AWs and WAW. The isoprene turnover is about one order of magnitude lower with an average figure of $0.06 \pm 0.07 \mathrm{~d}^{-1}$, which can be considered as a lower limit, since no relevant microbial consumption term can be used.

As shown in Figs. 6 and 7 and Table 4, there was a clear link between water masses and $\mathrm{CO} /$ propene concentrations. Several reasons can be considered to explain the dependence of $\mathrm{CO}$ or NMHC surface concentrations on temperature. A first possible effect could be purely physical and due to the dependence of the air-sea exchange velocity (piston veloc- ity) on the surface-seawater temperature, leading to a variation in the overall contribution of this sink in the budget of the water column and consequently of the residence time of $\mathrm{CO}$ or NMHC in the water column and of their accumulation rate. Lower temperatures associated with lower diffusivity coefficients and exchange speeds are in favor of an increase of $\mathrm{CO}$ or NMHC levels due to an increase of their residence time in the surface layers. For the range of temperatures observed $\left(\sim 6^{\circ} \mathrm{C}\right.$ in WAW, $\sim-1.5^{\circ} \mathrm{C}$ in PW), the variation of the piston velocity proportional to $S c^{-1 / 2}$ or $S c^{-2 / 3}$ is reduced by $30 \%$ from WAW to PW. Considering the contribution of the ventilation to the atmosphere to the global turnover previously estimated (12 to $24 \%$ ), it appears that the physical effect of temperature is therefore of secondary importance in the variability of the CO concentrations observed (2-fold variation) between WAW and PW.

For alkenes and isoprene, the effect of temperature leads to a relative change in the Schmidt number of roughly $50 \%$ between warm and cold waters. This physical effect of temperature is still not sufficient to explain the observed variability in the concentrations, which vary more than 2-fold between WAW and PW. The microbial consumption term, although highly uncertain and with a lower contribution than for CO, can significantly increase their residence time in colder PW masses.

In summary, the physical effect of temperature through the variation of the sea-air exchange term cannot explain the increase of $\mathrm{CO}$ and alkene surface-seawater concentrations observed in the Arctic Ocean; the variation of their residence time through the microbial consumption effect is probably a main factor to take into account.

\subsection{Photoproduction of $\mathrm{CO}$ and alkenes}

Numerous variables were considered to explain the observed variations in the surface concentrations of $\mathrm{CO}$ and propene. Solar radiation must be first considered owing to the frequently observed diurnal cycle of these compounds in stations. The average global radiation diurnal cycle is shown in Fig. 11a. The maximum solar radiation of $295 \pm 139 \mathrm{~W} \mathrm{~m}^{-2}$ occurred between 12:00 and 15:00 UTC, and minimum values were measured at night, with an average value of $31 \pm 15 \mathrm{~W} \mathrm{~m}^{-2}$. Compared with the average diurnal cycle of $\mathrm{CO}$ concentration over the cruise (Fig. 11b), in which no significant diurnal cycle was detected, solar radiation seemed not to be the dominant process that explained the $\mathrm{CO}$ variability at the surface. Although daily surface-seawater $\mathrm{CO}$ measurements were not performed during the whole period (due to station sampling), the measurements did not reveal any clear diurnal signals. These results are in agreement with the observations of Xie et al. (2009), who found that no diurnal cycle of surface-water $\mathrm{CO}$ concentration occurred in spring. Similarly, the alkene surface measurements, although conducted with a reduced spatial resolution, did not show any diurnal trends. 
Table 7. Estimated turnover $\left(\mathrm{day}^{-1}\right)$ of $\mathrm{CO}$ and isoprene in the mixed layer, and corresponding averaged production rates.

\begin{tabular}{|c|c|c|c|c|c|c|}
\hline Station $^{\circ} \mathrm{N}$ & $\begin{array}{l}\text { Water } \\
\text { mass }\end{array}$ & $\begin{array}{l}\text { Averaged } \\
\quad \text { chl } a \\
\mu \mathrm{g} \mathrm{L}^{-1 \mathrm{a}}\end{array}$ & $\begin{array}{c}\mathrm{CO} \\
\text { turnover } \\
\mathrm{d}^{-1}\end{array}$ & $\begin{array}{c}\mathrm{CO} \\
\text { production } \\
10^{-7} \mathrm{~mol} \mathrm{~m}^{-3} \mathrm{~d}^{-1}\end{array}$ & $\begin{array}{c}\text { Isoprene } \\
\text { turnover } \\
\mathrm{d}^{-1}\end{array}$ & $\begin{array}{c}\text { Isoprene } \\
\text { production } \\
\mu \mathrm{mol} \mathrm{g} \mathrm{chl} a^{-1} \mathrm{~d}^{-1}\end{array}$ \\
\hline $\mathrm{S} 1$ & AW & 3.56 & 0.89 & 15.5 & 0.046 & 0.20 \\
\hline $\mathrm{S} 2$ & PW & 0.24 & 0.06 & 0.57 & 0.015 & \\
\hline S5 & PW & & & & & \\
\hline S9 & PW & 0.30 & 0.08 & 0.76 & & \\
\hline S14 & PW & & & & & \\
\hline S20 & FAW & 3.27 & 1.71 & 11.9 & 0.018 & 0.29 \\
\hline S25 & FAW & 1.98 & 0.34 & 16.4 & 0.031 & 0.19 \\
\hline S41 & FAW & 2.94 & 1.60 & 11.2 & 0.045 & 0.37 \\
\hline S44 & FAW & 1.24 & 0.60 & 5.63 & 0.020 & 0.22 \\
\hline S64 & WAW & 0.71 & 0.35 & 2.10 & 0.040 & 1.57 \\
\hline S68 & WAW & 1.02 & 0.71 & 4.01 & 0.175 & 5.63 \\
\hline S102 & WAW & 2.73 & 0.67 & 14.6 & 0.006 & 0.16 \\
\hline S111 & AW & 0.92 & 0.44 & 7.70 & 0.022 & 0.77 \\
\hline S124 & AW & 1.90 & 0.96 & 12.6 & 0.009 & 0.23 \\
\hline $\mathrm{S} 129$ & AW & 1.43 & 0.69 & 11.8 & 0.010 & 0.25 \\
\hline S134 & AW & 0.97 & 0.53 & 5.30 & 0.074 & 4.34 \\
\hline S136 & AW & 0.43 & 0.20 & 3.74 & 0.041 & 2.23 \\
\hline S139 & WAW & 1.34 & 0.65 & 3.40 & 0.015 & 0.64 \\
\hline S157 & WAW & & & & & \\
\hline S167 & WAW & 0.98 & 0.48 & 2.04 & 0.025 & 0.81 \\
\hline S170 & AW & 0.92 & 0.41 & 3.93 & 0.004 & \\
\hline S173 & PW & 0.58 & & & 0.006 & 0.07 \\
\hline S179 & AW & 0.74 & 0.33 & 3.91 & 0.018 & 1.73 \\
\hline S182 & PW & 0.25 & 0.28 & 4.09 & 0.170 & 32.7 \\
\hline S185 & PW & 0.87 & 0.77 & 11.4 & 0.279 & 8.06 \\
\hline S194 & AW & 0.79 & 0.71 & 18.5 & 0.114 & 4.55 \\
\hline S200 & PW & 1.10 & 0.51 & 2.47 & 0.005 & 0.19 \\
\hline S203 & AW & 2.30 & & & 0.015 & 0.53 \\
\hline $\mathrm{S} 211$ & PW & 1.00 & & & 0.212 & 3.07 \\
\hline S216 & PW & 0.54 & 0.34 & 3.01 & 0.102 & 3.77 \\
\hline S224 & PW & 1.28 & 0.73 & 19.0 & 0.097 & 1.66 \\
\hline S229 & PW & 1.06 & 0.50 & 2.23 & 0.007 & 0.16 \\
\hline S237 & PW & 0.31 & 0.16 & 20.0 & 0.056 & 1.24 \\
\hline
\end{tabular}

${ }^{\text {a }}$ Chlorophyll depth weighted average.

The fluorescent signal of CDOM measured on board (Figs. 5b, 6b, 7b) was 5-fold greater in PW than in the other water masses. Several authors (Belzile et al., 2000; Scully and Miller, 2000) have noted the release of organic matter during ice melting due to algae growing in the ice, which might explain the generally higher values of CDOM in the ice-covered PW. An additional source of CDOM in sea ice could be the incorporation of detritus from rivers during ice development on the Siberian shelves (Nürnberg et al., 1994). The co-occurrence of $\mathrm{CO}$ and CDOM production in PW combined with UV radiation is known to be the main source of $\mathrm{CO}$ in seawater, and our observations confirmed this combination as a first-order process.

Fichot and Miller (2010) have recently studied and simulated the global production of $\mathrm{CO}$ by the photodegradation of CDOM based on monthly climatology, and Fig. 12 shows their estimates for our investigation area. Our spatial distributions of $\mathrm{CO}$ at the sea surface (Fig. 4a) can be compared to the output of their model, facilitating the description of similarities between our measured concentrations and their calculated production rate at the sea surface. From the turnover of $\mathrm{CO}$ evaluated in Table 7, we have derived average values of the production rate of $\mathrm{CO}$ in the mixed layer, which can be also compared. The hot spot of measured $\mathrm{CO}$ along the Greenland coast was unfortunately not documented in their model (Fig. 12a). Higher production rates were found in the west side of section 2 (at $75^{\circ} \mathrm{N}$ ) and along section 4 (transect north to south) before Jan Mayen Island. The CO measurements showed high concentrations in the same area from $75^{\circ} \mathrm{N}$ to $80^{\circ} \mathrm{N}$, where high values of CDOM were also 

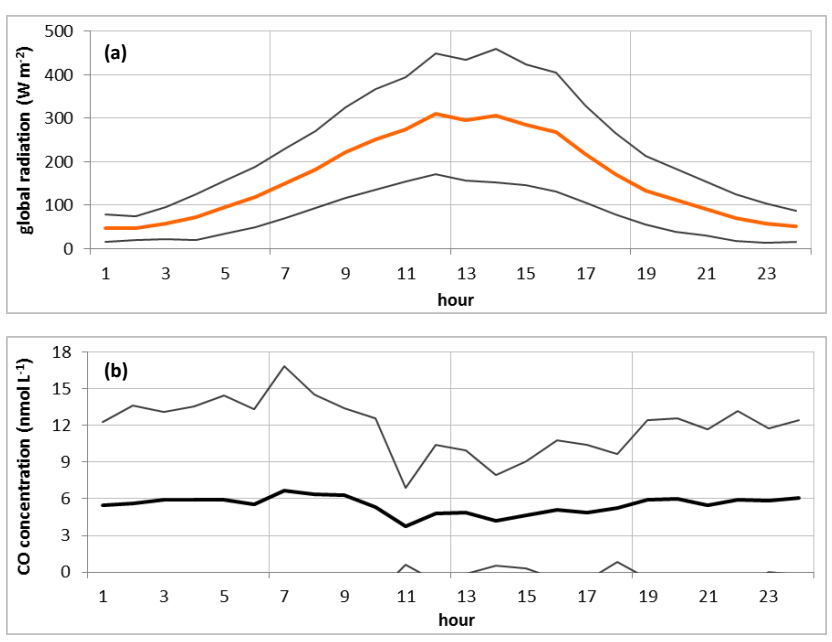

Fig. 11. (a) Average diurnal cycle of the solar radiation $\left(\mathrm{W} \mathrm{m}^{-2}\right)$ and (b) of $\mathrm{CO}\left(\mathrm{nmol} \mathrm{L}^{-1}\right)$ over the whole cruise (full solid line), with the standard deviation (light solid line).

found. In this area, the measured $\mathrm{CO}$ and $\mathrm{CDOM}$ values fitted with the photochemical production of $\mathrm{CO}$ at the sea surface as pointed out by Fichot and Miller; high $\mathrm{CO}$ average production rates in the mixed layer $\left(>1 \times 10^{-6} \mathrm{~mol} \mathrm{~m}^{-3} \mathrm{~d}^{-1}\right)$ deduced from our data at the stations s20, s25 and s 41 and at stations s224 and s237 close to the Greenland coast confirm this general pattern. However, the other areas with high production rates did not match with the variability of our measurements, demonstrating the limit of comparison between the production rates calculated per day on the basis of climatological databases and our local measurements at a given location.

The similar behavior of $\mathrm{CO}$ and alkenes suggests that their sources in oceanic waters have a common origin in the UVinduced photodecomposition of organic matter. This assumption is consistent with the comparison of the order of magnitude of their quantum yields $\Phi$ (in mole of $\mathrm{CO}$ or alkenes produced per mole of photon in UV absorbed by CDOM) with respect to photoproduction. This is however very limited since the sinks for $\mathrm{CO}$ and alkenes are probably quite different. Wavelength-weighted quantum yields of CO photoproduction have been estimated in various marine environments by different authors (Zafiriou et al., 2003; Zhang et al., 2006; Xie et al., 2009; Stubbins et al 2011), with a range of 1 to $5 \times 10^{-6}$ molecule photon ${ }^{-1}$ in the Amundsen Gulf (Xie et al., 2009). For alkenes, no specific data can be found in such marine environments, which excludes a direct comparison; however, quantum yields for alkenes photoproduction derived from studies at mid-latitudes (Riemer et al., 2000), or from laboratory experiments on seawater (Ratte et al., 1998), lead to values of 2 or 3 order of magnitude lower than for $\mathrm{CO}$ at the same latitudes $\left(\sim 9 \times 10^{-6}\right.$ molecule photon $^{-1}$; Zafiriou et al., 2003). This is also the range of the ratios of (a)

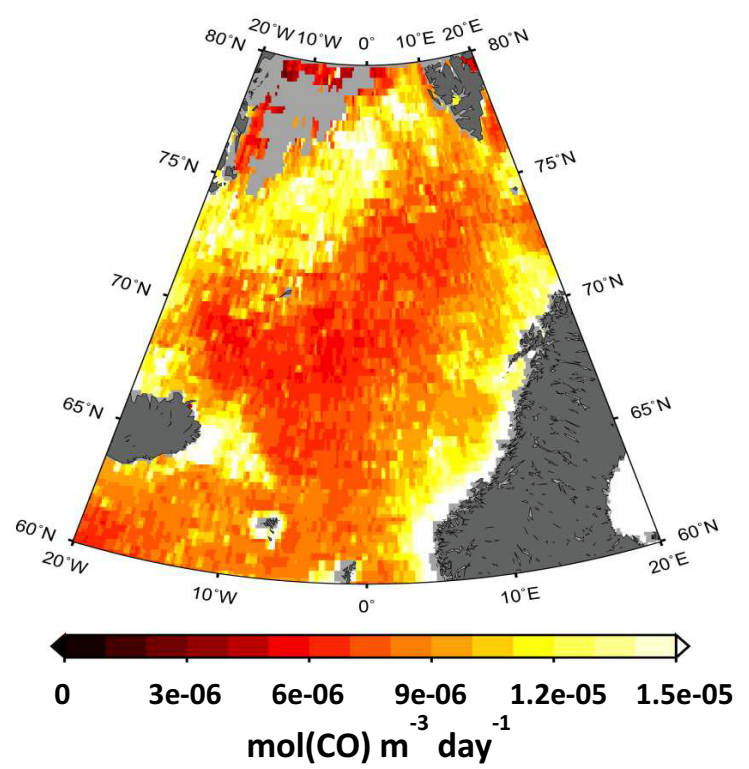

(b)

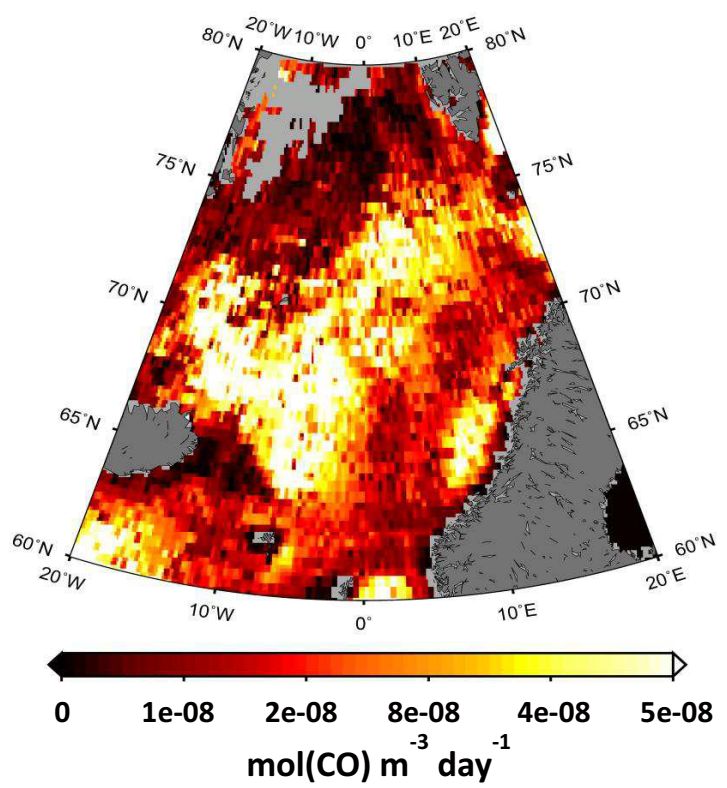

Fig. 12. Surface $\mathrm{CO}$ production (a) and $\mathrm{CO}$ production at a depth of $20 \mathrm{~m}$ (b) adapted from Fichot and Miller (2010), courtesy C. G. Fichot.

alkenes to CO that we have observed on surface seawater (Table 4); the hypothesis of a common photoproduction process for alkenes, and $\mathrm{CO}$ is consistent with our knowledge of the magnitude of their sources and sinks.

\subsection{Influence of biology on trace gas production}

However, in addition to these common fates characterizing the vertical distributions of $\mathrm{CO}$ and alkenes, a difference is the occurrence of relatively high, secondary deep 
CO concentrations, which were usually observed close to the chlorophyll maximum (purple dots in Fig. 1).

Considering that the photoproduction of $\mathrm{CO}$ is, at $20 \mathrm{~m}$ depth, 2 or 3 orders of magnitude lower than at the surface, according to the simulations of Fichot and Miller (2010), the occurrence of significant level of $\mathrm{CO}$ in depth can be attributed to downward transport by advection and diffusion. The CO profile would display in that case a regular decreasing trend according to the most frequently observed profiles; only a source "in situ" would be able to produce the observed deep relative maximum that we have noted on some specific profiles. Figure 13a-g present the vertical profiles of $\mathrm{CO}$, isoprene, chlorophyll and phytoplankton species at seven selected stations. At the five stations s124, s139, s167, s170 and s229 (Fig. 13a-e), a deviation from the decreasing profile following the light penetration was found for $\mathrm{CO}$. Among those stations, this deviation of $\mathrm{CO}$ concentration with depth (most pronounced at station s167) usually aligned with the maximum of chlorophyll $a$ or occurred slightly above this maximum of chlorophyll $a$. For comparison, two other stations (s179 and s182), where no deviation was observed for $\mathrm{CO}$, are reported in Fig. 13f and g.

A mechanism of photoproduction by particles previously described by Xie et al. (2009) can be first considered, but it would involve the presence of UV radiations at this depth and it is consequently much less probable owing to the profile of UV penetration generally observed. The degradation of pigments or phytoplanktonic components under PAR radiation, still available at theses depths, is also one other possible mechanism to be considered (Nelson, 1993; Rontani, 2001 and references therein). However, a previous study of Gros et al. (2009) based on laboratory experiments on phytoplankton cultures has shown that $\mathrm{CO}$ was produced directly from phytoplankton groups exposed to PAR in the absence of UV radiation, and that no production occurred on the filtered media, which excludes a possible photoproduction mechanism on CDOM at these wavelengths. These considerations therefore strongly suggest an origin of this secondary CO maximum linked to biologically related processes.

Concerning the vertical isoprene profiles for these five stations, the deep subsurface maximum aligned with the maximum chlorophyll $a$ concentration and the $\mathrm{CO}$ secondary maximum previously discussed. At station s124 measured on the Fram Strait close to Spitsbergen, a profile of isoprene showed two maxima, the first one at 5-10 m depth and the second one at $20-25 \mathrm{~m}$ depth, exactly as the chlorophyll $a$ profile, which was represented by mostly Phaeocystis-type algae. Associated with the $\mathrm{CO}$ profiles of s167, a station also on the Fram Strait, the maximum isoprene value occurred at the maximum value of chlorophyll $a$ concentration between 20 and $30 \mathrm{~m}$ depth. The peaks of isoprene seemed to be driven once again by Phaeocystis-type algae but also by dinoflagellates and to a lesser extent by diatom species and one species of chlorophyte. At station s179 $\left(79.7^{\circ} \mathrm{N}\right.$, Fig. 13f), the isoprene depth profile indicated a maximum of concentration at $15 \mathrm{~m}$ depth, the same as the maximum of chlorophyll $a$ concentration. This chlorophyll $a$ maximum was driven by a combination of several algae groups, such as Phaeocystis, coccolithophorids, prasinophytes and dinoflagellates. Among those species, prasinophytes seemed to drive the isoprene concentration at $15 \mathrm{~m}$ depth. At station $\mathrm{s} 182$ (Fig. 13g), the most northern station $\left(79.9^{\circ} \mathrm{N}\right)$, the maxima of isoprene and chlorophyll $a$ concentrations were governed by diatoms and coccolithophorids.

The maximum isoprene level was observed for most of the stations at the same depth as the chlorophyll $a$ maximum, or slightly above this maximum. This offset between these maxima has already been observed previously by Bonsang et al. (1992) and Milne et al. (1995), who suggested that there might be no direct link between isoprene and chlorophyll and that isoprene could rather be produced by the degradation of an organic precursor. However, Moore et al. (1994) note that the total rate of photosynthesis is a function not only of chlorophyll content but also of the light intensity, which decreases exponentially through the water column. Therefore, these authors suggested observing the level of maximum isoprene lying above the chlorophyll maximum. Finally, McKay et al. (1996) and Shaw et al. (2003) assumed that isoprene appears during phytoplankton growth and is most likely produced either directly by the plankton or through the oxidation of exuded dissolved organic carbon.

From the vertical profiles of the compounds and their corresponding abundance in the water column, a biological production rate (Table 8) could be inferred. The estimations of the $\mathrm{CO}$ production through this secondary biological process are made by considering the difference $\Delta Q$ in the water column content between the observed $\mathrm{CO}$ profile and the $\mathrm{CO}$ profile fitted without this secondary maximum (assuming a quasi-exponential decrease). This excess is then normalized to the chlorophyll concentration measured at these levels to obtain $\mu \mathrm{g}$ of CO per $\mathrm{g}$ of chlorophyll and, then, using the average turnover $\tau$ (Table 7):

$P_{\mathrm{CO}, \text { bio }}=\tau \Delta Q$.

This calculation leads to values from 16.5 to $63.4 \mu \mathrm{mol} \mathrm{COgchl} a^{-1} \mathrm{~d}^{-1}$ (mean value of $46.1 \mu \mathrm{mol} \mathrm{COg}$ chl $a^{-1} \mathrm{~d}^{-1}$ ). Comparing the CO profiles to the species-concentration profiles, we have observed that Phaeocystis, dinoflagellates and to a lesser extent diatoms were dominant when this deviation appeared. The average value calculated from our five stations with an additional source of $\mathrm{CO}$ appears to be in the lower range of the diatom production rates determined in the laboratory. Indeed, Gros et al. (2009), working on several species of phytoplankton, have found production rates ranging from 19 to $374 \mu \mathrm{mol} \mathrm{CO} \mathrm{g} \mathrm{chl} a^{-1} \mathrm{~d}^{-1}$ for diatoms (with a median value of $33 \mu \mathrm{molCOgchl} a^{-1} \mathrm{~d}^{-1}$ ), between 115 and $344 \mu \mathrm{mol} \mathrm{CO} \mathrm{g} \mathrm{chl} a^{-1} \mathrm{~d}^{-1}$ for cyanobacteria and values of 56 and $6 \mu \mathrm{mol} \mathrm{CO} \mathrm{g} \mathrm{chl} a^{-1} \mathrm{~d}^{-1}$ for the coccolithophorid and chlorophyte, respectively. Unfortunately, no Phaeocystis or 


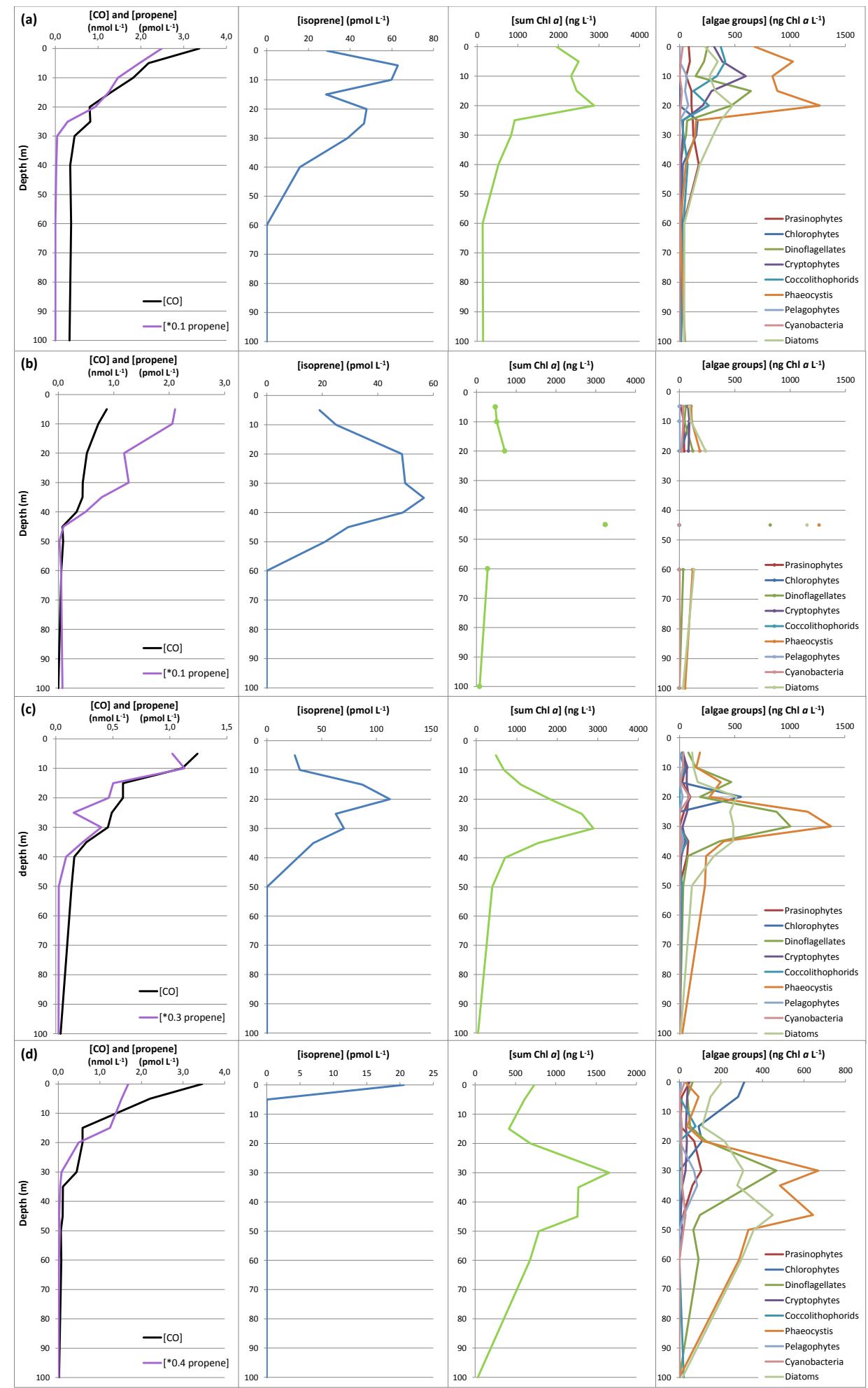

Fig. 13. Profiles of $\mathrm{CO}\left(\mathrm{nmol} \mathrm{L}^{-1}\right)$, propene (values have been multiplied by a factor $x$ to fit in the $\mathrm{CO}$ figure, pmol $\mathrm{L}^{-1}$ ), isoprene $\left(\right.$ pmol L $\left.{ }^{-1}\right)$, chlorophyll $a\left(\mathrm{ng} \mathrm{L}^{-1}\right)$ levels and abundances of phytoplankton $\left(\mathrm{ng} \operatorname{chl} a \mathrm{~L}^{-1}\right)$ for stations s124 (a), s139 (b), s167 (c), s170 (d), s229 (e), s179 (f) and s182 (g). 


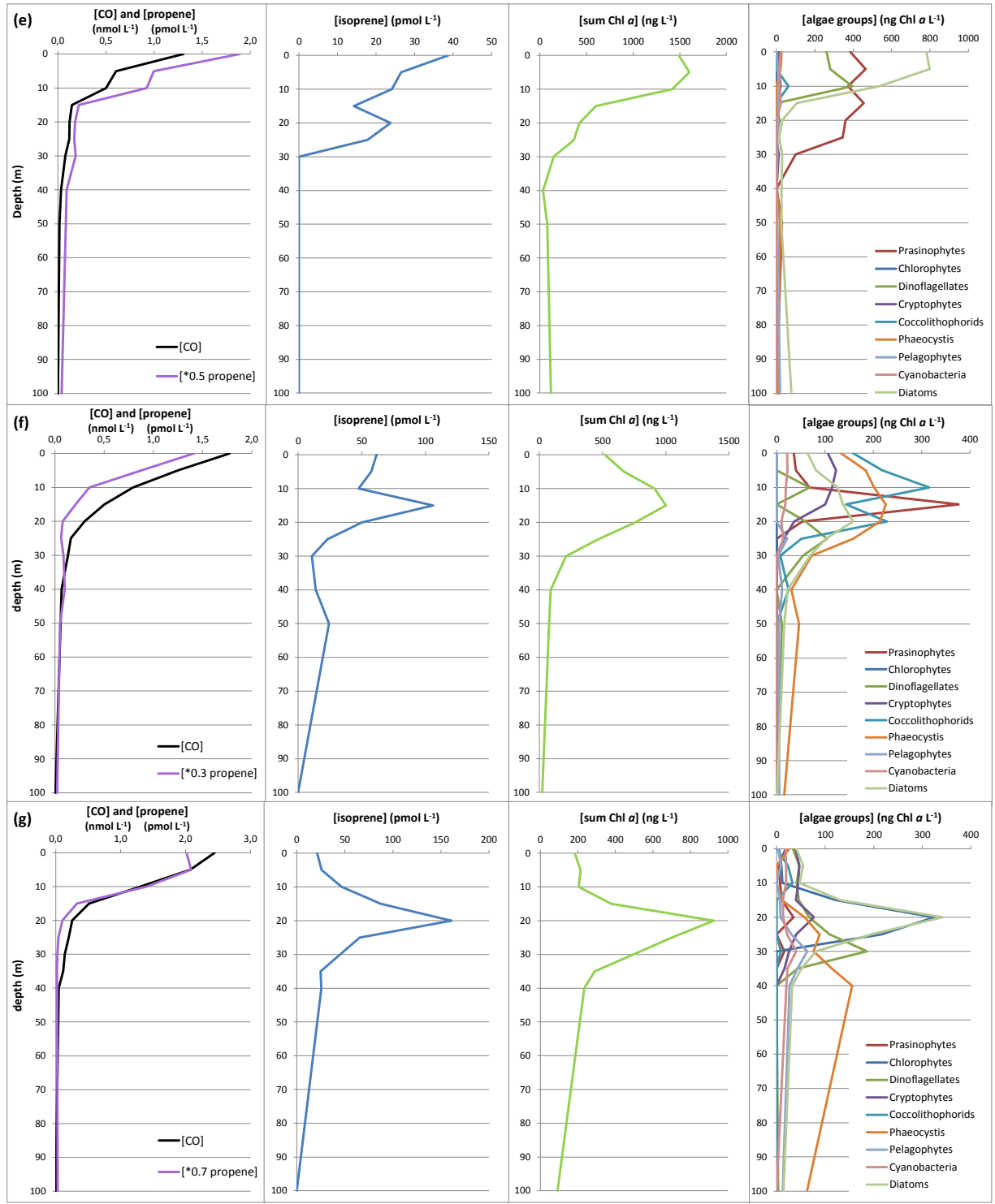

Fig. 13. Continued.

Table 8. CO production rate ( $\mu \mathrm{g} \mathrm{COg} \mathrm{chl} a^{-1} \mathrm{~h}^{-1}$ and $\left.\mu \mathrm{mol} \mathrm{COg} \mathrm{chl} a^{-1} \mathrm{~d}^{-1}\right)$ calculated for the five stations at which a biological production of $\mathrm{CO}$ was observed in the mixed layer. $Z_{\mathrm{ML}}$ is the depth of the mixed layer. For isoprene, the average and median production rate in the mixed layer was also calculated for all of the depth profiles.

\begin{tabular}{lccccc}
\hline Station & $\begin{array}{c}Z_{\mathrm{ML}^{*}} \\
(\mathrm{~m})\end{array}$ & $\begin{array}{c}\text { Ratio CO/Chl } \\
\left(\mathrm{g} \mathrm{COg} \mathrm{chl} a^{-1}\right)\end{array}$ & $\begin{array}{c}\mathrm{CO} \text { production } \\
\left(\mu \mathrm{g} \mathrm{COg} \mathrm{chl} a^{-1} \mathrm{~h}^{-1}\right)\end{array}$ & $\begin{array}{c}\text { CO production } \\
\left(\mu \mathrm{g} \mathrm{CO} \mathrm{g} \mathrm{chl} a^{-1} \mathrm{~h}^{-1} \mathrm{~d}^{-1}\right)\end{array}$ & $\begin{array}{c}\text { Isoprene production } \\
\left(\mu \mathrm{mol} \mathrm{C} \mathrm{H}_{8} \mathrm{~g} \mathrm{chl}^{-1} \mathrm{~d}^{-1}\right)\end{array}$ \\
\hline s124 & 30 & $1.85 \times 10^{-3}$ & 74.0 & 63.4 & 0.23 \\
s139 & 45 & $2.08 \times 10^{-3}$ & 56.3 & 48.3 & 0.64 \\
s167 & 50 & $9.60 \times 10^{-4}$ & 19.2 & 16.5 & 0.81 \\
s170 & 40 & $4.00 \times 10^{-3}$ & 68.3 & 58.6 & 0.16 \\
s229 & 18 & $2.46 \times 10^{-3}$ & 51.3 & 43.9 & 0.46 \\
\hline Average (these 5 stations) & & 53.8 & 46.1 & $1.65(0.71)$ \\
\hline Average (median) & & & & \\
for all of the depth profiles & & & & \\
\hline
\end{tabular}


Table 9. CO and isoprene production rates determined in laboratory experiments on selected phytoplankton species by (1) Gros et al. 2009; (2) Bonsang et al. 2010; and (3) Shaw et al., 2003.

\begin{tabular}{|c|c|c|c|c|}
\hline \multirow[t]{2}{*}{ Species } & \multirow[t]{2}{*}{ Name } & \multirow{2}{*}{$\begin{array}{c}\begin{array}{c}\text { CO production rate } \\
\left(\mu \mathrm{mol} \mathrm{COg} \mathrm{chl} a^{-1} \mathrm{~d}^{-1}\right)\end{array} \\
(1)\end{array}$} & \multicolumn{2}{|c|}{$\begin{array}{c}\text { Isoprene production rate } \\
\left(\mu \mathrm{mol} \mathrm{C}_{5} \mathrm{H}_{8} \mathrm{gChl} a^{-1} \mathrm{~d}^{-1}\right)\end{array}$} \\
\hline & & & (2) & (3) \\
\hline \multirow{2}{*}{ Cyanobacteria } & Trichodesmium & 344 & 3.00 & \\
\hline & Synechococcus & 115 & 4.97 & 1.4 \\
\hline Coccolithophorid & Emiliania Huxleyi & 56 & 1.0 & 1.0 \\
\hline Chlorophyte & Dunaliella tertiolecta & 6 & 0.4 & \\
\hline \multirow{2}{*}{ Diatom (cold water) } & Fragilariopsis kerguelensis & 65 & 0.56 & \\
\hline & Chaetoceros debilis & 374 & 0.65 & \\
\hline \multirow{3}{*}{ Diatom (temperate water) } & Phaeodactylum tricornutum & 33 & 1.12 & \\
\hline & Chaetoceros neogracilis & 21 & 1.26 & \\
\hline & Skeletonema costatum & 19 & 1.32 & 1.8 \\
\hline
\end{tabular}

dinoflagellates have been measured in the laboratory. Despite the lack of diurnal survey of the $\mathrm{CO}$ profiles in the water column, a large uncertainty characterizes our estimates, which should be considered only as order of magnitude, since the $\mathrm{CO}$ concentration should significantly change at time scales of hours. Nevertheless, our observations were thus consistent with the occurrence of a possible secondary mechanism of $\mathrm{CO}$ production driven by in situ biological processes.

For isoprene, similar calculations were conducted in the mixed layer, considering the ventilation to the atmosphere as the dominant sink. Isoprene production rates are on the average of $1.65( \pm 0.71) \mu \mathrm{mol} \mathrm{C}_{5} \mathrm{H}_{8} \mathrm{gchl} a^{-1} \mathrm{~d}^{-1}$ and of $0.46 \mu \mathrm{mol} \mathrm{C}_{5} \mathrm{H}_{8} \mathrm{~g}$ chl $a^{-1} \mathrm{~d}^{-1}$ for the five stations where a secondary $\mathrm{CO}$ maximum was observed in the mixed layer. We can compare these production rates based on our in situ measurements with values from the literature based on laboratory experiments (Table 9).

The mean isoprene production rate was in the range of production by diatoms and coccolithophorids reported by Shaw et al. (2003) and Bonsang et al. (2010). However, we must note that the isoprene production was highly algae-group dependent, and only a few species were studied in the laboratory. Moreover, the light conditions of the laboratory experiments included PAR irradiance of approximately 75 to $100 \mu \mathrm{E} \mathrm{m}^{-2} \mathrm{~s}^{-1}$, which is slightly greater than the conditions of our field experiment.

\section{Conclusion}

A dataset of $\mathrm{CO}$ and NMHC concentrations combined with biological measurements in high latitudes of the Arctic Ocean is described. High variability of $\mathrm{CO}$ and propene was observed in the depth profiles and at the seawater surface. The photodegradation of CDOM by light radiation was the main identified process for $\mathrm{CO}$ and alkene production, and the vertical profiles of $\mathrm{CO}$ and alkenes in the water column were consequently driven by light penetration. However, at the surface, the global solar radiation was not the main parameter that influenced the variability of the sea-surface concentrations; indeed, no $\mathrm{CO}$ or alkene diurnal cycles were observed. Polar water showed a significant enhancement of $\mathrm{CO}$ and alkene surface concentrations by a combination of two effects: a reduction of the mixed-layer depth, in accordance with a strong stratification and density gradient within the first $10 \mathrm{~m}$, and an increase of the CDOM concentration. Seaair fluxes of $\mathrm{CO}$ and alkenes estimated for theses oceanic areas correspond to the highest range of values generally observed over the oceans.

Biomass activity was also found to be an important parameter. We have observed for the first time through in situ measurements that $\mathrm{CO}$ could be partly produced by a secondary mechanism linked to the phytoplankton. Compared to laboratory studies, this biological source of $\mathrm{CO}$ was of the same order of magnitude as that previously estimated for diatoms under PAR radiation. In addition to these observations, we have also confirmed the direct influence of biology on the production of isoprene and have shown that the isoprene production was species-dependent. However, further work is needed to better characterize the role of sea ice in the source of CO and NMHC and to identify and quantify the main sinks of isoprene and other NMHC in the water column.

\section{Appendix A}

\section{Determination of the extraction yield}

The theoretical extraction yield can be defined as the ratio of the mass of the volatile organic compound (VOC) extracted in the gas phase to the initial mass in the water analyzed. Assuming that the VOC concentration in the gas phase of volume $V_{\mathrm{g}}$ is in equilibrium (infinite contact time) with the concentration in the water phase of volume $V_{\mathrm{w}}$, according to Henry's equilibrium, the theoretical extraction yield $\mu$ is 
given by the following equation:

$\mu=\frac{\frac{V_{\mathrm{g}}}{V_{\mathrm{w}}}}{\frac{V_{\mathrm{g}}}{V_{\mathrm{w}}}+K_{\mathrm{h}} \mathrm{RT}}$,

where $K_{\mathrm{h}}$ is the Henry's law constant in $\mathrm{mol} \mathrm{L}^{-1} \mathrm{~atm}^{-1}$, and $R$ is the perfect gas constant in corresponding units $\left(0.08206 \mathrm{~L} \mathrm{~atm} \mathrm{~K}^{-1} \mathrm{~mol}^{-1}\right)$.

In our experimental conditions, the ratio $V_{\mathrm{g}} / V_{\mathrm{w}}$ is also equal to the ratio of the flow rate of gas $\left(F_{\mathrm{g}}\right)$ to the flow rate of water $\left(F_{\mathrm{W}}\right)$ in the extraction cell, and Eq. (A1) becomes

$\mu=\frac{\frac{F_{\mathrm{g}}}{F_{\mathrm{w}}}}{\frac{F_{\mathrm{g}}}{F_{\mathrm{w}}}+K_{\mathrm{h}} \mathrm{RT}}$.

The experimental extraction yield $\left(\mu_{\exp }\right)$ is dependent on the time of contact between the gas phase and the aqueous phase and various parameters, including the diffusion coefficients of VOC in the water phase and geometrical factors, such as the internal section of the coil of the cell. The yield can be experimentally determined by measuring the gas-phase concentration in the extraction cell flushed with a water sample containing a known amount or concentration of the hydrocarbon. However, this method requires the precise determination of the initial concentration in the water sample, which itself requires knowledge of the experimental extraction yield. To avoid a relatively complex procedure involving several iterative steps, we used a simple method consisting of performing the extraction in a closed system so that the initial VOC concentration is not required a priori. In the experimental design described in Fig. A1, the total volume of water is $V_{\mathrm{w}}$ (in the flask and extraction device), and the total initial VOC amount in the system $Q_{0}$ is calculated as follows:

$Q_{0}=C_{\mathrm{w}, 0} V_{\mathrm{w}}$,

where $C_{\mathrm{w}, 0}$ is the unknown initial VOC concentration and $C_{\mathrm{w}, t}$ is the VOC concentration at time $t$.

Assuming an extraction efficiency $\mu$, the amount of VOC removed per unit time from the water at a flow rate $F_{\mathrm{w}}$ in the extraction cell is given by the following equation:

$\frac{\mathrm{d} Q_{t}}{\mathrm{~d} t}=\frac{V_{\mathrm{w}} \mathrm{d} C_{\mathrm{w}, t}}{\mathrm{~d} t}=-\mu_{\exp } F_{\mathrm{w}} C_{\mathrm{w}, t}$,

which leads to the following calculation:

$C_{\mathrm{w}, t}=C_{\mathrm{W}, 0} \exp \left(-\mu_{\exp } \frac{F_{\mathrm{w}}}{V_{\mathrm{w}}} t\right)$

or

$\ln \frac{C_{\mathrm{w}, t}}{C_{\mathrm{W}, 0}}=-\mu_{\exp } \frac{F_{\mathrm{w}}}{V_{\mathrm{w}}} t$.

As the concentration in the gas phase $C_{\mathrm{g}, t}$ is directly proportional to $C_{\mathrm{w}, t}$, the extraction efficiency $\mu_{\exp }$ is deduced from the slope $\ln \frac{C_{\mathrm{w}, t}}{C_{\mathrm{W}, 0}}$ plotted versus the time $t$, i.e., of the exponential decrease of the concentration of the VOC measured in the gas phase in the extraction device.

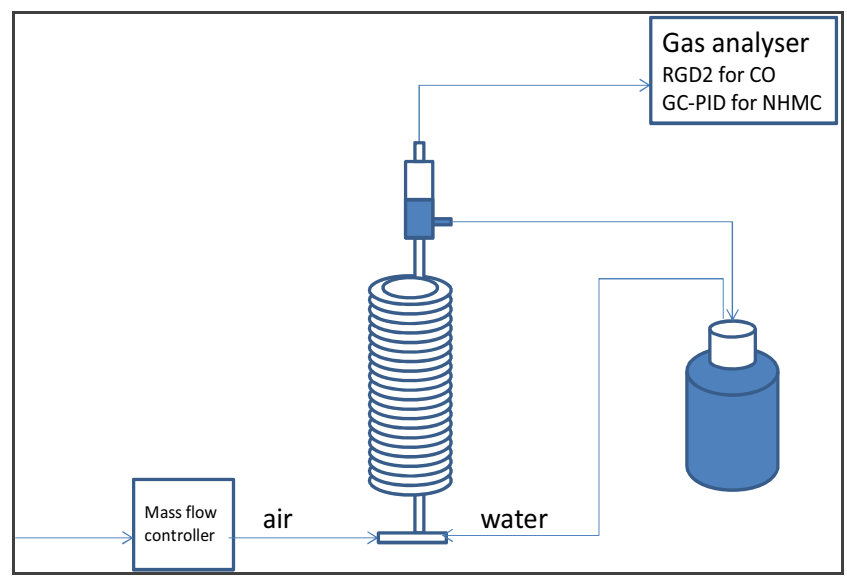

Fig. A1. Principle of the closed system.

\section{Appendix B}

\section{Air-sea exchange: numerical determination of the "piston velocity"}

The piston velocity or air-sea exchange velocity $K_{\mathrm{w}}$ (in $\mathrm{cm} \mathrm{h}^{-1}$ ) of a given compound that is supersaturated in seawater is given by applying the parameterization of Liss and Merlivat (1986):

$K_{\mathrm{w}}=0.17 . u\left(\frac{S c}{600}\right)^{-\frac{2}{3}}$

for $u \leq 3.6 \mathrm{~m} \mathrm{~s}^{-1}$ and

$K_{\mathrm{w}}=(2.85 . u-9.65)\left(\frac{S c}{600}\right)^{-\frac{1}{2}}$

for $3.6<u \leq 13 \mathrm{~m} \mathrm{~s}^{-1}$ or Wanninkhof (1992):

$K_{\mathrm{w}}=0.31 \cdot u^{2}\left(\frac{S c}{660}\right)^{-\frac{1}{2}}$,

where $u\left(\mathrm{~m} \mathrm{~s}^{-1}\right)$ is the wind velocity at $10 \mathrm{~m}$. The Schmidt number $S c$ (dimensionless) is given by the ratio $S c=\frac{v}{D}$, where $v$ is the kinematic viscosity of water $\left(\right.$ in $^{2} \mathrm{~s}^{-1}$ ) and $D$ is the diffusivity of the considered species in water. $D$, which is dependent on temperature, is calculated by applying the classic Wilke and Chang (1955) equation:

$D=7.4 \times 10^{-8} \frac{\sqrt{\gamma M}}{\eta V_{\mathrm{a}}^{0.6}} T$,

where $\eta$ is the viscosity of seawater (in centipoise or $\left.10^{-2} \mathrm{~g} \mathrm{~cm}^{-1} \mathrm{~s}^{-1}\right) ; \gamma$ is the association factor (2.6 for water); $M$ is the molar mass of water in $\mathrm{g} \mathrm{mol}^{-1} ; T$ is the temperature of seawater $\left({ }^{\circ} \mathrm{K}\right) ; V_{\mathrm{a}}$ is the molar volume of the considered species. 


\section{Appendix C}

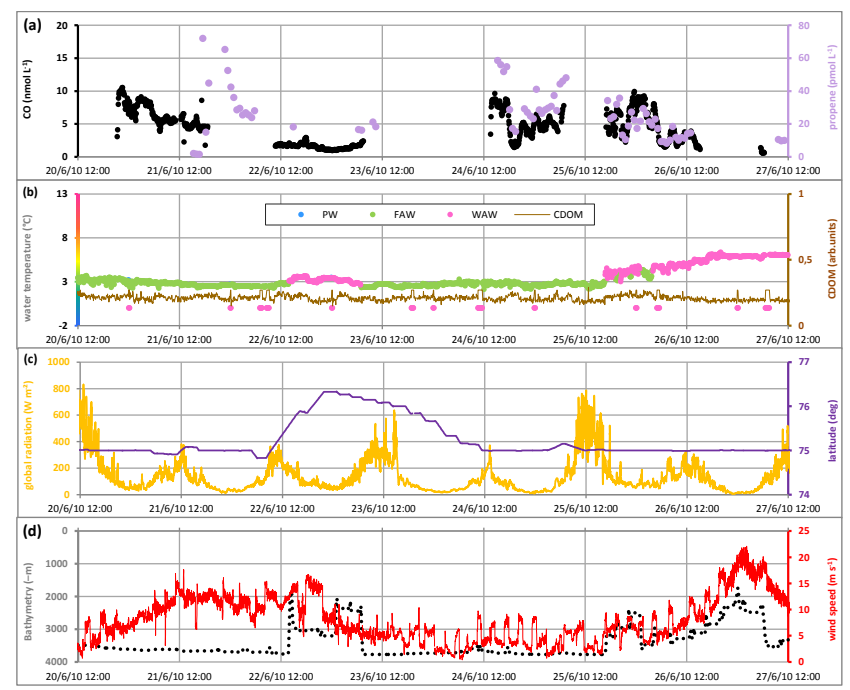

Fig. C1. (a) Sea-surface CO $\left(\mathrm{nmol} \mathrm{L}^{-1}\right)$ and propene $\left(\mathrm{pmol} \mathrm{L}^{-1}\right)$ concentrations; (b) water temperature $\left({ }^{\circ} \mathrm{C}\right)$, which included the identification of water masses: $\mathrm{PW}=$ polar water, FAW $=$ fresh Atlantic water, $\mathrm{WAW}=$ warm Atlantic water, AWs = Atlantic water with low salinity, and CDOM concentration (ppb); (c) global radiation $\left(\mathrm{W} \mathrm{m}^{-2}\right)$ and latitude (deg); and (d) bathymetry (m) and wind speed $\left(\mathrm{m} \mathrm{s}^{-1}\right)$ for section two.

Acknowledgements. This project was funded by the Egide (Procope) program common to the German and French Ministries of Foreign Affairs. We thank the captain and crew of the R/V Polarstern and the chief scientists Gereon Budeus and Thomas Soltwedel for their support. We thank the AWI for supporting the experiment on board the R/V Polarstern and for access to logistic and data facilities. Specials thanks are due to the FerryBox group from the Helmholtz-Zentrum Geesthacht for the CDOM data and Gereon Budeus (AWI) for the density data. CNRS and CEA are acknowledged for additional support. We are grateful to Diana Ruiz-Pino (Laboratoire d'océanographie et du climat, Paris) for very helpful discussions, and to the anonymous reviewers for their constructive comments.

\section{Edited by: K. Suzuki}

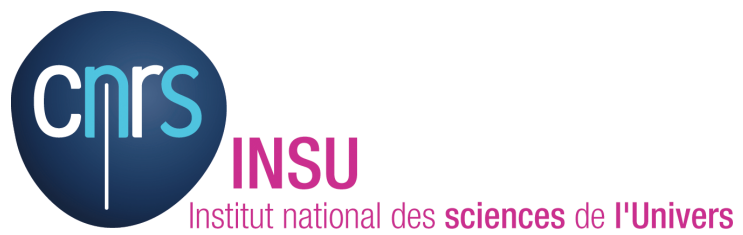

The publication of this article is financed by CNRS-INSU.

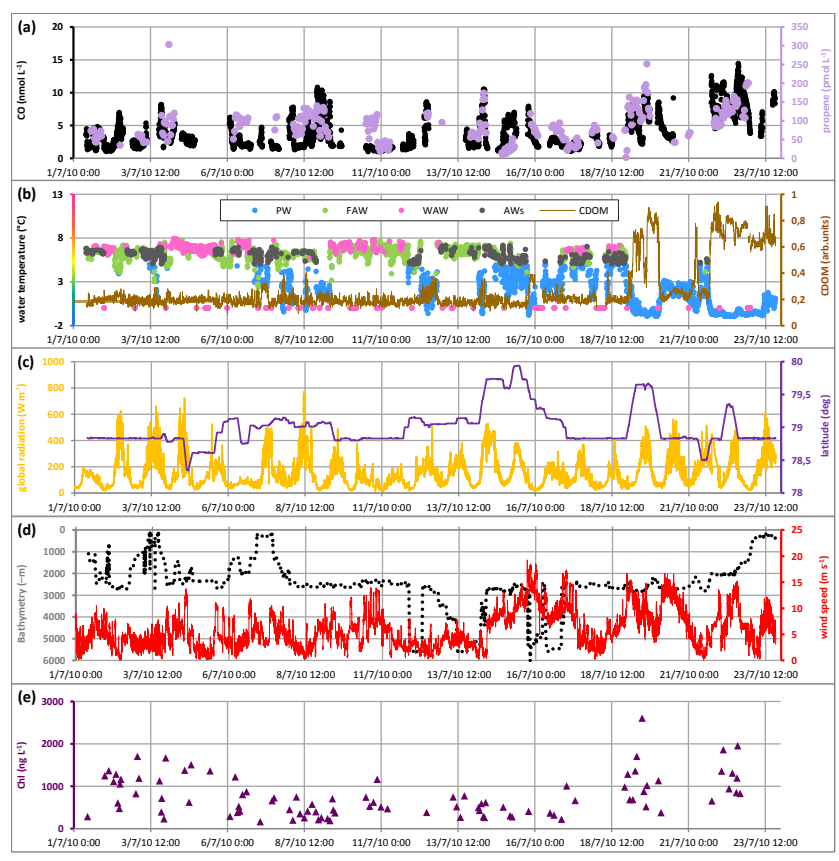

Fig. C2. (a) Sea-surface CO $\left(\mathrm{nmol} \mathrm{L}^{-1}\right)$ and propene $\left(\mathrm{pmol} \mathrm{L}^{-1}\right)$ concentrations; (b) water temperature $\left({ }^{\circ} \mathrm{C}\right)$, which included the identification of water masses: $\mathrm{PW}=$ polar water, FAW $=$ fresh Atlantic water, WAW $=$ warm Atlantic water, $\mathrm{AWs}=$ Atlantic water with low salinity, and CDOM concentration (ppb); (c) global radiation $\left(\mathrm{W} \mathrm{m}^{-2}\right)$ and latitude (deg); and (d) bathymetry $(\mathrm{m})$ and wind speed $\left(\mathrm{m} \mathrm{s}^{-1}\right)$ for section three.

\section{References}

Alvarez, L. C., Exton, D. A., Timmis, K. N., Suggett, D. J., and McGenity, T. J.: Characterization of marine isoprenedegrading communities, Environ. Microbiol., 11, 3280-3291, doi:10.1111/j.1462-2920.2009.02069.x, 2009.

Arnold, S. R., Spracklen, D. V., Williams, J., Yassaa, N., Sciare, J., Bonsang, B., Gros, V., Peeken, I., Lewis, A. C., Alvain, S., and Moulin, C.: Evaluation of the global oceanic isoprene source and its impacts on marine organic carbon aerosol, Atmos. Chem. Phys., 9, 1253-1262, doi:10.5194/acp-9-1253-2009, 2009.

Atkinson, R.: Tropospheric reactions of the haloalkyl radicals formed from hydroxyl radical reaction with a serie of alternative fluorocarbons, in: Scientific Assessment of Stratospheric Ozone: 1989, World Meteorological Organization Global Ozone Research and Monitoring Project - Report No. 20, II, 165-205, Appendix: AFEAS Report, Geneva, Switzerland, 1990.

Ayers, G. P., Cainey, J. M., Gillett, R. W., Saltzman, E. S., and Hooper, M.: Sulfur dioxide and dimethyl sulfide in marine air at Cape Grim, Tasmania, Tellus B, 49, 292-299, 1997.

Barlow, R. G., Cummings, D. G., and Gibb, S. W.: Improved resolution of mono- and divinyl chlorophylls $\mathrm{a}$ and $\mathrm{b}$ and zeaxanthin and lutein in phytoplankton extracts using reverse C-8 HPLC, Mar. Ecol.-Prog. Ser., 161, 303-307, 1997.

Bates, T. S., Kelly, K. C., Johnson, J. E., and Gammon, R. H.: Regional and seasonal variations in the flux of oceanic carbon monoxide to the atmosphere, J. Geophys. Res., 100, 23093 
23101, doi:10.1029/95JD02737, 1995.

Belzile, C., Johannessen, S. C., Gosselin, M., Demers, S., and Miller, W. L.: Ultraviolet attenuation by dissolved and particulate constituents of first-year ice during late spring in an arctic polynya, Limnol. Oceanogr., 45, 1265-1273, doi:10.4319/lo.2000.45.6.1265, 2000.

Bidigare, R. R.: Analysis of algal chlorophylls and carotenoids, in: Marine particles: Analysis and characterisation, edited by: Hurd, D. C. and Spencer, D. W., American Geophysical Union, 119123, 1991.

Blindheim, J. and Rey, F.: Water-mass formation and distribution in the Nordic Seas during the 1990s, ICES J. Mar. Sci., 61, 846863, doi:10.1016/j.icesjms.2004.05.003, 2004.

Bonsang, B., Kanakidou, M., Lambert, G., and Monfray, P.: The marine source of $\mathrm{C}_{2}-\mathrm{C}_{6}$ aliphatic hydrocarbons, J. Atmos. Chem., 6, 3-20, doi:10.1007/BF00048328, 1988.

Bonsang, B., Polle, C., and Lambert, G.: Evidence of marine production of isoprene, Geophys. Res. Lett., 19, 1129-1132, doi:10.1029/92GL00083, 1992.

Bonsang, B., Polle, C., and Lambert, G.: Production of nonmethane hydrocarbons by seawater, Ann. Inst. Oceanogr., 69, 125-128, 1993.

Bonsang, B., Gros, V., Peeken, I., Yassaa, N., Bluhm, K., Zoellner, E., Sarda-Esteve, R., and Williams, J.: Isoprene emission from phytoplankton monocultures: the relationship with chlorophyll $a$, cell volume and carbon content, Environ. Chem., 7, 554-563, doi:10.1071/EN09156, 2010.

Brakstad, O. G. and Bonaunet K.: Biodegradation of petroleum hydrocarbons in seawater at low temperatures $(0-5$ degrees $C)$ and bacterial communities associated with degradation, Biodegradation, 17, 71-82, doi:10.1007/s10532-005-3342-8, 2006.

Broadgate, W. J., Liss, P. S., and Penkett, S. A.: Seasonal emissions of isoprene and other reactive hydrocarbon gases from the ocean, Geophys. Res. Lett., 24, 2675-2678, doi:10.1029/97GL02736, 1997.

Gammon, R. H. and Kelly, K. C.: Photochemical production of carbon monoxide in surface waters of the Pacific and Indian oceans, in: Effects of Solar Ultraviolet Radiation of Biogeochemical Dynamics in Aquatic Environments, edited by: Blough, N. V. and Zepp, R. G., Woods Hole Oceanographic Institution, Woods Hole, Mass, WHOI-90-09, 58-60, 1990.

Carslaw, N., Creasey, D. J., Heard, D. E., Lewis, A. C., McQuaid, J. B., Pilling, M. J., Monks, P. S., Bandy, B. J., and Penkett, S. A.: Modeling $\mathrm{OH}, \mathrm{HO} 2$, and $\mathrm{RO} 2$ radicals in the marine boundary layer -1 . Model construction and comparison with field measurements, J. Geophys. Res.-Atmos., 104, 30241-30255, doi:10.1029/1999JD900783, 1999.

Cauwet, G. and Sidorov, I.: The biogeochemistry of lena river: Organic carbon and nutrients distribution, Mar. Chem., 53, 211227, doi:10.1016/0304-4203(95)00090-9, 1996.

Claeys, M., Graham, B., Vas, G., Wang, W., Vermeylen, R., Pashynska, V., Cafmeyer, J., Guyon, P., Andreae, M. O., Artaxo, P., and Maenhaut, W.: Formation of secondary organic aerosols through photooxidation of isoprene, Science, 303, 1173-1176, doi:10.1126/science.1092805, 2004.

Conrad, R., Seiler, W., Bunse, G., and Giehl, H.: Carbon monoxide in sea-water (Atlantic Ocean), J. Geophys. Res.-Oc. Atm., 87, 8839-8852, doi:10.1029/JC087iC11p08839, 1982.
Crutzen, P. J.: Global budgets for non- $\mathrm{CO}_{2}$ greenhouse gases, Environ. Monit. Assess., 31, 1-15, doi:10.1007/bf00547177, 1994.

Day, D. A. and Faloona, I.: Carbon monoxide and chromophoric dissolved organic matter cycles in the shelf waters of the northern California upwelling system, J. Geophys. Res.-Oceans, 114, C01006, doi:10.1029/2007JC004590, 2009.

Eilertsen, H.-C. and Holm-Hansen, O.: Effects of high latitude UV radiation on phytoplankton and nekton modeled from field measurements by simple algorithms, Polar Res., 19, 173-182, doi:10.1111/j.1751-8369.2000.tb00341.x, 2000.

Erickson III, D. J.: Ocean to atmosphere carbon monoxide flux: global inventory and climate implications, Global Biogeochem. Cy., 3, 305-314, doi:10.1029/GB003i004p00305, 1989.

Erickson, D. J. and Taylor, J. A.: 3-D tropospheric CO modeling - the possible influence of the ocean, Geophys. Res. Lett., 19, 1955-1958, doi:10.1029/92g101475, 1992.

Fall, R. and Copley, S. D.: Bacterial sources and sinks of isoprene, a reactive atmospheric hydrocarbon, Environ. Microbiol., 2, 123130, doi:10.1046/j.1462-2920.2000.00095.x, 2000.

Fichot, C. G. and Miller, W. L.: An approach to quantify depthresolved marine photochemical fluxes using remote sensing: Application to carbon monoxide (CO) photoproduction, Remote Sens. Environ., 114, 1363-1377, doi:10.1016/j.rse.2010.01.019, 2010.

Frey, K. E. and Smith, L. C.: Amplified carbon release from vast west siberian peatlands by 2100 , Geophys. Res. Lett., 32, L09401, doi:10.1029/2004g1022025, 2005.

Gantt, B., Meskhidze, N., and Kamykowski, D.: A new physicallybased quantification of marine isoprene and primary organic aerosol emissions, Atmos. Chem. Phys., 9, 4915-4927, doi:10.5194/acp-9-4915-2009, 2009.

Gantt, B., Meskhidze, N., Zhang, Y., and Xu, J.: The effect of marine isoprene emissions on secondary organic aerosol and ozone formation in the coastal United States, Atmos. Environ., 44, 115121, doi:10.1016/j.atmosenv.2009.08.027, 2010.

Gibson, J. A. E., Vincent, W. F., and Pienitz, R.: Hydrologic control and diurnal photobleaching of CDOM in a subarctic lake, Arch Hydrobiol., 152, 143-159, 2001.

Gros, V., Peeken, I., Bluhm, K., Zollner, E., Sarda-Esteve, R., and Bonsang, B.: Carbon monoxide emissions by phytoplankton: Evidence from laboratory experiments, Environ. Chem., 6, 369379, doi:10.1071/en09020, 2009.

Guenther, A., Hewitt, C. N., Erickson, D., Fall, R., Geron, C., Gradel, T., Harley, P., Klinger, L., Lerdau, M., McKay, W. A., Pierce, T., Scholes, B., Steinbrecher, R., Tallamraju, R., Taylor, J., and Zimmerman, P.: A global model of natural volatile organic-compound emissions, J. Geophys. Res.-Atmos., 100, 8873-8892, doi:10.1029/94JD02950, 1995.

Guenther, A., Karl, T., Harley, P., Wiedinmyer, C., Palmer, P. I., and Geron, C.: Estimates of global terrestrial isoprene emissions using MEGAN (Model of Emissions of Gases and Aerosols from Nature), Atmos. Chem. Phys., 6, 3181-3210, doi:10.5194/acp-63181-2006, 2006.

Häder, D.-P., Kumar, H. D., Smith, R. C., and Worrest, R. C.: Effects of solar UV radiation on aquatic ecosystems and interactions with climate change, Photochem. Photobiol., 6, 267-285, 2007.

Hudson, E. D. and Ariya, P. A.: Measurements of nonmethane hydrocarbons, DOC in surface ocean waters 
and aerosols over the Nordic seas during Polarstern cruise ARK-XX/1 (2004), Chemosphere, 69, 1474-1484, doi:10.1016/j.chemosphere.2007.04.056, 2007.

Jeffrey, S. W. and Vesk, M.: Introduction to marine phytoplankton and their pigment signatures, in: Phytoplankton pigments in oceanography: Guideline to modern methods., edited by: Jeffrey, S. W., Mantoura, R. F. C., and Wright, S. W., 10, UNESCO Publishing, Paris, 37-84, 1997.

Johnson, J. E. and Bates, T. S.: Sources and sinks of carbon monoxide in the mixed layer of the tropical South Pacific Ocean, Global Biogeochem. Cy., 10, 347-359, doi:10.1029/96GB00366, 1996.

Jones, R. D.: Carbon-monoxide and methane distribution and consumption in the photic zone of the Sargasso Sea, Deep-Sea Res. I, 38, 625-635, doi:10.1016/0198-0149(91)90002-w, 1991.

Kanakidou, M., Seinfeld, J. H., Pandis, S. N., Barnes, I., Dentener, F. J., Facchini, M. C., Van Dingenen, R., Ervens, B., Nenes, A., Nielsen, C. J., Swietlicki, E., Putaud, J. P., Balkanski, Y., Fuzzi, S., Horth, J., Moortgat, G. K., Winterhalter, R., Myhre, C. E. L., Tsigaridis, K., Vignati, E., Stephanou, E. G., and Wilson, J.: Organic aerosol and global climate modelling: a review, Atmos. Chem. Phys., 5, 1053-1123, doi:10.5194/acp-5-1053-2005, 2005.

Kettle, A. J.: Diurnal cycling of carbon monoxide (CO) in the upper ocean near Bermuda, Ocean Model., 8, 337-367, doi:10.1016/j.ocemod.2004.01.003, 2005.

Kroll, J. H. and Seinfeld, J. H.: Chemistry of secondary organic aerosol: Formation and evolution of low-volatility organics in the atmosphere, Atmos. Environ., 42, 3593-3624, doi:10.1016/j.atmosenv.2008.01.003, 2008.

Lee, R. F. and Baker, J.: Ethylene and ethane production in an estuarine river - formation from the decomposition of polyunsaturated fatty-acids, Mar. Chem., 38, 25-36, doi:10.1016/03044203(92)90065-i, 1992.

Lewis, A. C., McQuaid, J. B., Carslaw, N., and Pilling, M. J.: Diurnal cycles of short-lived tropospheric alkenes at a north Atlantic coastal site, Atmos. Environ., 33, 2417-2422, doi:10.1016/S1352-2310(98)00429-4, 1999.

Lewis, A. C., Carpenter, L. J., and Pilling, M. J.: Nonmethane hydrocarbons in Southern Ocean boundary layer air, J. Geophys. Res.-Atmos., 106, 4987-4994, doi:10.1029/2000JD900634, 2001.

Liakakou, E., Vrekoussis, M., Bonsang, B., Donousis, C., Kanakidou, M., and Mihalopoulos, N.: Isoprene above the Eastern Mediterranean: Seasonal variation and contribution to the oxidation capacity of the atmosphere, Atmos. Environ., 41, 10021010, doi:10.1016/j.atmosenv.2006.09.034, 2007.

Linnenbom, V. J., Swinnerton, J. W., and Lamontagne, R. A.: Ocean as a source for atmospheric carbon-monoxide, J. Geophys. Res., 78, 5333-5340, doi:10.1029/JC078i024p05333, 1973.

Liss, P. S., and Merlivat, L.: Air-sea gas exchange rates: Introduction and synthesis, in: The Role of Air-Sea Exchange in Geochemical Cycling, edited by: Buat-Ménard, P., Springer, New York, 113-127, 1986.

Logan, J., Prather, M. J.,Wofsy, S. C., and McElroy, M. B.: Tropospheric chemistry: A global perspective, J. Geophys. Res.Atmos., 86, 7210-7254, doi:10.1029/JC086iC08p07210, 1981.

Mackey, M. D., Mackey, D. J., Higgings, H. W., and Wright, S. W.: "CHEMTAX" - a program for estimating class abundances from chemical markers: Application to HPLC measure- ments of phytoplankton, Mar. Ecol.-Prog. Ser., 144, 265-283, doi:10.3354/meps144265, 1996.

McKay, W. A., Turner, M. F., Jones, B. M. R., and Halliwell, C. M.: Emissions of hydrocarbons from marine phytoplankton - some results from controlled laboratory experiments, Atmos. Environ., 30, 2583-2593, doi:10.1016/1352-2310(95)00433-5, 1996.

Mill, T., H. Richardson, and Hendry D. G.: Oxidation of organic compounds in aquatic systems: The free radical oxidation of cumene, in: Aquatic Pollutants: Transformation and Biological Effects, edited by: Hutzinger O., Van Lelyveld I. H., and Zoeteman B. C., 223-236, Elsevier, New York, 1978.

Milne, P. J., Riemer, D. D., Zika, R. G., and Brand, L. E.: Measurement of vertical-distribution of isoprene in surface seawater, its chemical fate, and its emission from several phytoplankton monocultures, Mar. Chem., 48, 237-244, doi:10.1016/03044203(94)00059-m, 1995.

Moore, R. M., Oram, D. E., and Penkett, S. A.: Production of isoprene by marine phytoplankton cultures, Geophys. Res. Lett., 21, 2507-2510, doi:10.1029/94GL02363, 1994.

Müller, J.-F., Stavrakou, T., Wallens, S., De Smedt, I., Van Roozendael, M., Potosnak, M. J., Rinne, J., Munger, B., Goldstein, A., and Guenther, A. B.: Global isoprene emissions estimated using MEGAN, ECMWF analyses and a detailed canopy environment model, Atmos. Chem. Phys., 8, 1329-1341, doi:10.5194/acp-81329-2008, 2008.

Nelson, J. R.: Rates and possible mechanism of light-dependent degradation of pigments in detritus derived from phytoplankton, J. Mar. Res., 51, 155-179, doi:10.1357/0022240933223837, 1993.

Nightingale, P. D., Malin, G., Law, C. S., Watson, A. J., Liss, P. S., Liddicoat, M. I., Boutin, J., and Upstill-Goddard, R. C.: In situ evaluation of air-sea gas exchange parameterizations using novel conservative and volatile tracers, Global Biogeochem. Cy., 14, 373-387, doi:10.1029/1999GB900091, 2000.

Nürnberg, D., Wollenburg, I., Dethleff, D., Eicken, H., Kassens, H.,Letzig, T., Reimnitz, E., and Thiede, J.: Sediments in Arctic sea ice: Implications for entrainment, transport and release, Mar. Geol., 119, 185-214, doi:10.1016/0025-3227(94)90181-3, 1994.

Ohta, K.: Diurnal variations of carbon monoxide in the Equatorial Pacific upwelling region, J. Oceanogr., 53, 173-178, 1997.

Opsahl, S., Benner, R., and Amon, R. M. W.: Major flux of terrigenous dissolved organic matter through the Arctic Ocean, Limnol. Oceanogr., 44, 2017-2023, doi:10.4319/lo.1999.44.8.2017, 1999.

Palmer, P. I. and Shaw, S. L.: Quantifying global marine isoprene fluxes using modis chlorophyll observations, Geophys. Res. Lett., 32, L09805, doi:10.1029/2005GL022592, 2005.

Plass-Dülmer, C., Koppmann, R., Ratte, M., and Rudolph, J.: Light nonmethane hydrocarbons in seawater, Global Biogeochem. Cy., 9, 79-100, doi:10.1029/94GB02416, 1995.

Prather, M. J.: Time scales in atmospheric chemistry: Theory, GWPs for $\mathrm{CH}_{4}$ and $\mathrm{CO}$, and runaway growth, Geophys. Res. Lett., 23, 2597-2600, doi:10.1029/96gl02371, 1996.

Prather, M. J., Ehhalt, D., Dentener, F., Derwent, R., Dlugokencky, E., Holland, E., Isaksen, I., Katima, J., Kirchhoff, V., Matson, P., Midgley, P., and Wang, M.: Chapter 4: Atmospheric chemistry and greenhouse gases, in: Climate Change 2001: The scientific basis, edited by: Houghton, J. T., Ding, Y., Griggs, D. J., Noguer, M., van der Linden, P. J., Dai, X., Maskell, K., and John- 
son, C. A., Contribution of working group 1 to the third assessment report of the intergovernmental panel on climate change, Cambridge University Press, Cambridge, 239-287, 2001.

Rasmussen, R. A. and Went, F. W.: Volatile organic material of plant origin in atmosphere, P. Natl. Acad. Sci. USA, 53, 215220, doi:10.1073/pnas.53.1.215, 1965.

Ratte, M., Plass-Dülmer, C., Koppmann, R., Rudolph, J., and Denga, J.: Production mechanism of $\mathrm{C} 2-\mathrm{C} 4$ hydrocarbons in seawater - field-measurements and experiments, Global Biogeochem. Cy., 7, 369-378, doi:10.1029/93gb00054, 1993.

Ratte, M., Bujok, O., Spitzy, A., and Rudolph, J.: Photochemical alkene formation in seawater from dissolved organic carbon: Results from laboratory experiments, J. Geophys. Res.- Atmos., 103, 5707-5717, doi:10.1029/97JD03473, 1998.

Retamal, L., Vincent, W. F., Martineau, C., and Osburn, C. L.: Comparison of the optical properties of dissolved organic matter in two river-influenced coastal regions of the Canadian Arctic, Estuar. Coast. Shelf Sci., 72, 261-272, doi:10.1016/j.ecss.2006.10.022, 2007.

Rhee, T. S.: The process of air-water exchange and its application, PhD Thesis, 2000.

Riemer, D. D., Milne, P. J., Zika, R. G., and Pos, W. H.: Photoproduction of nonmethane hydrocarbons (NMHCs) in seawater, Mar. Chem., 71, 177-198, doi:10.1016/S0304-4203(00)00048-7, 2000.

Rontani, J.-F.: Visible light-dependent degradation of lipidic phytoplanktonic components during the senescence: a review, Phytochemistry, 58, 187-202, doi:10.1016/S0031-9422(01)00202-3, 2001.

Rudels, B., Jones, E. P., Schauer, U., and Eriksson, P.: Atlantic sources of the Arctic Ocean surface and halocline waters, Polar Res., 23, 181-208, doi:10.1111/j.1751-8369.2004.tb00007.x, 2004.

Rudoph, J. and Ehhalt, D. H.: Measurements of $\mathrm{C}_{2}-\mathrm{C}_{5}$ hydrocarbons over the North Atlantic, J. Geophys. Res.-Oc. Atm., 86, 1959-1964, doi:10.1029/JC086iC12p11959, 1981.

Sander, R.: Compilation of Henry's Law Constants for Inorganic and Organic Species of Potential Importance in Environmental Chemistry, 20, Max-Planck Institute of Chemistry, Air Chemistry Dept., available at: http://www.ceset.unicamp. br $\sim$ mariaacm/ST405/Lei\%20de\%20Henry.pdf, (last access: 6 September 2011), 1999.

Schlichtholz, P. and Houssais, M. N.: An inverse modeling study in fram strait, Part II: Water mass distribution and transports, DeepSea Res. II, 46, 1137-1168, doi:10.1016/s0967-0645(99)00017X, 1999.

Scully, N. M. and Miller, W. L.: Spatial and temporal dynamics of colored dissolved organic matter in the north water polynya, Geophys. Res. Lett., 27, 1009-1011, doi:10.1029/1999g1007002, 2000.

Shaw, S. L., Chisholm, S. W., and Prinn, R. G.: Isoprene production by prochlorococcus, a marine cyanobacterium, and other phytoplankton, Mar. Chem., 80, 227-245, doi:10.1016/s03044203(02)00101-9, 2003.

Shaw, S. L., Gantt, B., and Meskhidze, N.: Production and emissions of marine isoprene and monoterpenes, a review, Adv. Meteorol., 2010, Article ID 408696, 24 pp., doi:10.1155/2010/408696, 2010
Shennan, J. L.: Utilisation of $\mathrm{C}_{2}-\mathrm{C}_{4}$ gaseous hydrocarbons and isoprene by microorganisms, J.Chem. Technol. Biot., 81, 237-256, doi:10.1002/jctb.1388, 2006.

Stramski, D., Reynolds, R. A., Babin, M., Kaczmarek, S., Lewis, M. R., Röttgers, R., Sciandra, A., Stramska, M., Twardowski, M. S., Franz, B. A., and Claustre, H.: Relationships between the surface concentration of particulate organic carbon and optical properties in the eastern South Pacific and eastern Atlantic Oceans, Biogeosciences, 5, 171-201, doi:10.5194/bg-5-171-2008, 2008.

Stubbins, A., Uhera, G., Kitidis, V., Law, C. S., Upstill-Goddard, R. C., and Woodward, E. M. S.: The open-ocean source of atmospheric carbon monoxide, Deep-Sea Res. II, 53, 1685-1694, doi:10.1016/j.dsr2.2006.05.010, 2006.

Stubbins, A., Law, C. S., Uher, G., and Upstill-Goddard, R. C.: Carbon monoxide apparent quantum yields and photoproduction in the Tyne estuary, Biogeosciences, 8, 703-713, doi:10.5194/bg-8703-2011, 2011.

Swinnerton, J. W. and Lamontagne, R. A.: Carbon monoxide in south pacific ocean, Tellus, 26, 136-142, doi:10.3402/tellusa.v26i1-2.9744, 1974.

Swinnerton, J. W., Linnenbom. V. J., and Lamontagne, R. A.: Distribution of carbon monoxide between atmosphere and ocean, Anna. NY Acad. Sci., 174, 96-101,doi:10.1111/j.17496632.1970.tb49776.x, 1970.

Thompson, A. M.: The oxidizing capacity of the earth atmosphere - probable past and future changes, Science, 256, 1157-1165, doi:10.1126/science.256.5060.1157, 1992.

Tolli, J. D. and Taylor, C. D.: Biological CO oxidation in the Sargasso Sea and in Vineyard Sound, Massachussetts. Limnol. Oceanogr., 50, 1205-1212, doi:10.4319/lo.2005.50.4.1205, 2005.

Tsigaridis, K. and Kanakidou, M.: Global modelling of secondary organic aerosol in the troposphere: a sensitivity analysis, Atmos. Chem. Phys., 3, 1849-1869, doi:10.5194/acp-3-1849-2003, 2003.

Wängberg, S.-A., Andreasson, K. I. M., Gustavson, K., Reinthaler, T., and Henriksen, P.: UV-B effects on microplankton communities in Kongfjord, Svalbard - A mesocosm experiment, J. Exp. Mar. Biol. Ecol., 365, 156-163, doi:10.1016/j.jembe.2008.08.010, 2008.

Wanninkhof, R.: Relationship between wind-speed and gasexchange over the ocean, J. Geophys. Res.-Oceans, 97, 73737382, doi:10.1029/92JC00188, 1992.

Wheeler, P. A., Watkins, J. M., and Hansing, R. L.: Nutrients, organic carbon and organic nitrogen in the upper water column of the arctic ocean: Implications for the sources of dissolved organic carbon, Deep-Sea Res. II, 44, 1571-1592, doi:10.1016/S09670645(97)00051-9, 1997.

Wilke, C. R. and Chang, P.: Correlation of diffusion coefficients in dilute solutions, AICHE J., I, 264-270, doi:10.1002/AIC.690010222, 1955.

Wilson, D. F., Swinnerton, J., and Lamontagne, R.: Production of carbon monoxide and gaseous hydrocarbons in seawater - relation to dissolved organic carbon, Science, 168, 1576-1577, doi:10.1126/science.168.3939.1577, 1970.

Xie, H. and Zafiriou, O. C.: Evidence for significant photochemical production of caron monoxide by particles in coastal and oligotrophic marine waters, Geophys. Res. Lett., 36, L23606, doi:10.1029/2009GL041158, 2009. 
Xie, H. X., Zafiriou, O. C., Wang, W., and Taylor, C. D.: A simple automated continuous flow equilibration method for measuring carbon monoxide in seawater, Environ. Sci. Technol., 35, 14751480, doi:10.1021/es001656v, 2001.

Xie H., Zafiriou O. C., Umile T. P., and Kieber D. J.: Biological consumption of carbon monoxide in Delaware Bay, NW Atlantic and Beaufort Sea., Mar. Ecol.-Prog. Ser., 290, 1-14, doi:10.3354/meps290001, 2005.

Xie, H. X., Belanger, S., Demers, S., Vincent, W. F., and Papakyriakou, T. N.: Photobiogeochemical cycling of carbon monoxide in the southeastern Beaufort Sea in spring and autumn, Limnol. Oceanogr., 54, 234-249, doi:10.4319/lo.2009.54.1.0234, 2009.

Yang, G.-P., Ren, C.-Y., Lu, X.-L., Liu, C.-Y., and Ding, H.-B.: Distribution, flux, and photoproduction of carbon monoxide in the East China Sea and Yellow Sea in spring, J. Geophys. Res., 116, C02001, doi:10.1029/2010JC006300, 2011.

Yaws, C. L. and Yang, H.-C.: Henry's law constant for compound in water, in: Thermodynamic and Physical Property Data, edited by: C. L. Yaws, 181-206, Gulf Publishing Company, Houston, TX, 1992.
Zafiriou, O. C., Andrews, S. S., and Wang, W.: Concordant estimates of oceanic carbon monoxide source and sink processes in the pacific yield a balanced global "Blue-water" CO budget, J. Global Biogeochem. Cy., 17, 1015, doi:10.1029/2001gb001638, 2003.

Zafiriou, O. C., Xie, H., Nelson, N. B., Najjar, R. G., and Wang,W.: Diel carbon monoxide cycling in the upper Sargasso Sea near Bermuda at the onset of spring and in midsummer, Limnol. Oceanogr., 53, 835-850, doi:10.4319/lo.2008.53.2.0835, 2008.

Zhang, Y., Xie, H. X., Fichot, C. G., and Chen, G. H.: Dark production of carbon monoxide (CO) from dissolved organic matter in the St. Lawrence estuarine system: Implication for the global coastal and blue water CO budgets, J. Geophys. Res.-Oceans, 113, C12020, doi:10.1029/2008JC004811, 2008.

Zimmerman, P. R., Greenberg, J. P., and Westberg, C. E.: Measurements of atmospheric hydrocarbons and biogenic emission fluxes in the Amazon boundary-layer, J. Geophys. Res.-Atmos., 93, 1407-1416, doi:10.1029/JD093iD02p01407, 1988.

Zuo, Y. and Jones, R. D.: Formation of carbon-monoxide by photolysis of dissolved marine organic material and its significance in the carbon cycling of the oceans, Naturwissenschaften, 82, 472474, doi:10.1007/BF01131598, 1995. 